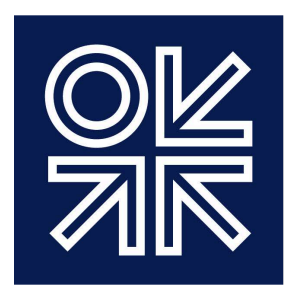

THE OXFORD

INSTITUTE

FOR ENERGY

STUDIES

\title{
Protection against Default in Long Term \\ Petroleum Joint Ventures
}

Eduardo Pereira

WPM 47

May 2012 
The contents of this paper are the authors' sole responsibility. They do not necessarily represent the views of the Oxford Institute for Energy Studies or any of its members.

Copyright C 2012

Oxford Institute for Energy Studies

(Registered Charity, No. 286084)

This publication may be reproduced in part for educational or non-profit purposes without special permission from the copyright holder, provided acknowledgment of the source is made. No use of this publication may be made for resale or for any other commercial purpose whatsoever without prior permission in writing from the Oxford Institute for Energy Studies.

ISBN

$978-1-907555-47-3$ 


\section{Contents}

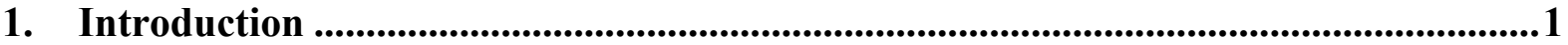

2. Default and the default provision ............................................................................................6

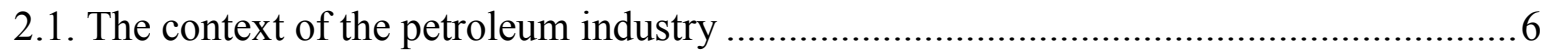

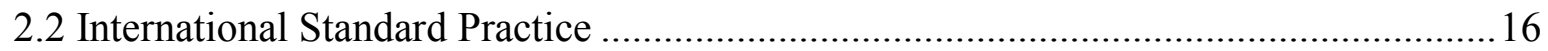

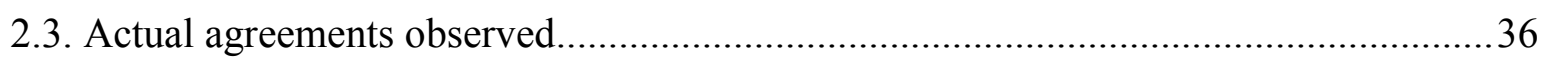

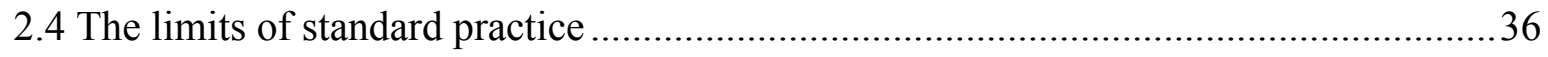

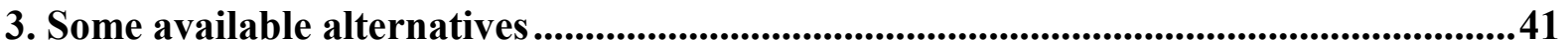

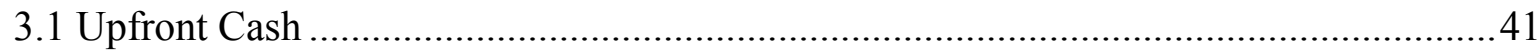

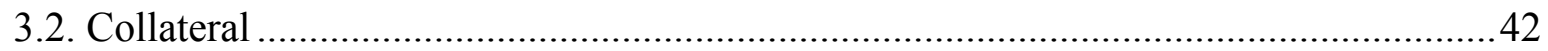

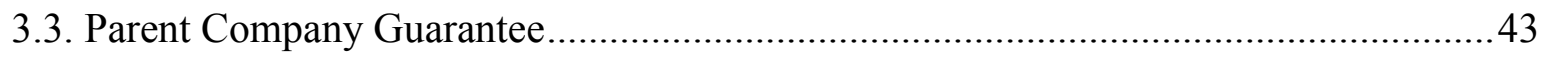

3.4. Bank Guarantees, Letters of Credit and Insurance-Guarantees ................................. 43

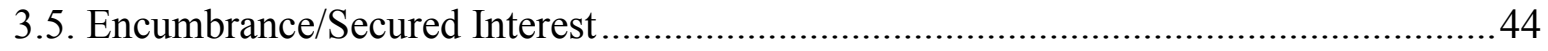

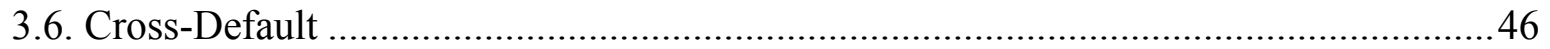

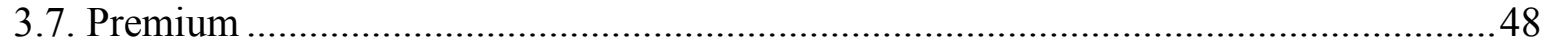

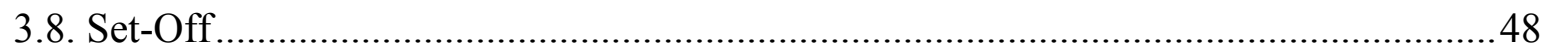

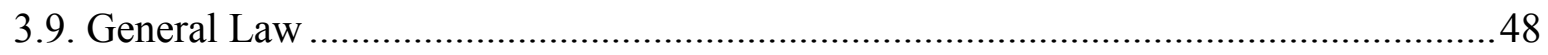

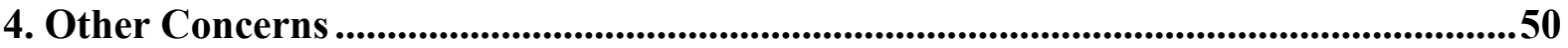

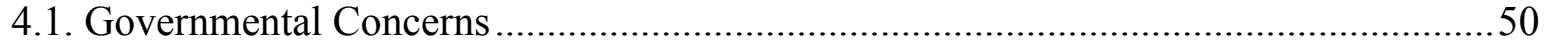

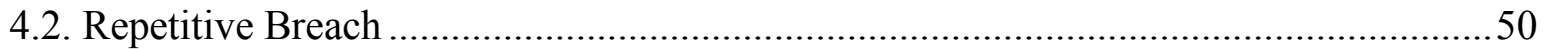

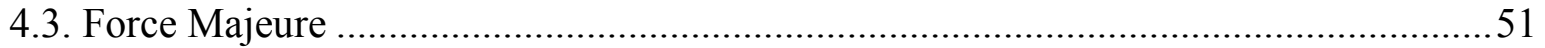

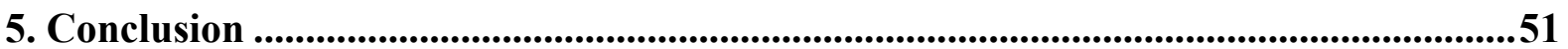

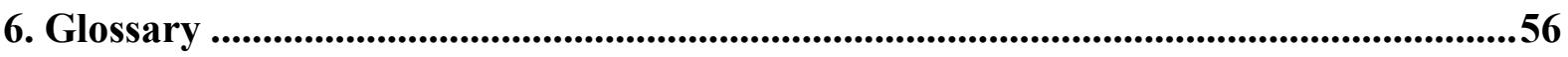

6. Sources and Bibliography ..........................................................................................................59 


\section{Introduction}

Upstream projects in the petroleum industry, especially during their exploration phase, are inherently risky from several points of view - technical, environmental and political. ${ }^{1}$ Downstream activities take place in a less adverse environment because most of the uncertainties mentioned above have already been overcome by the time the project actually takes place.

The ultimate goal of any private company is to make a profit. ${ }^{2}$ This means that financial expenditures are a critical issue for any private company but especially for oil and gas companies, since the capital required for oil and gas exploration and production is extremely onerous even for major companies. A good example of this is the ultra-deepwater reserves located in the offshore coast of Brazil known as the 'pre-salt' area. ${ }^{3}$ It is expected that nearly US $\$ 1$ trillion dollars will be needed to develop these deepwater reserves. ${ }^{4}$ Petrobras ${ }^{5}$, has announced that its investment plan for blocks located in the pre-salt area will cost more than US\$224 billion between 2011 and $2015 .^{6}$

Given these risks and expenses, oil and gas companies, even majors, prefer to combine their efforts in joint ventures. ${ }^{7}$ Sharing costs and risks are the basic foundation of any joint

\footnotetext{
${ }^{1}$ See also: Bill Manning, 'Some Practical Aspects of Resources Joint Ventures' in W. D. Duncan, Joint Ventures in Australia ( $2^{\text {nd }}$ edn The Federation Press, Sydney 2005) 322, Bernard. G. Taverne, Petroluem, Industry and Governments: A study of the Involvement of Industry and Government with the Production and use of Petroleum ( $2^{\text {nd }}$ edn Kluwer Law International, Alphen aan den Rijn 2008) 380 and Charlotte J. Wright and Rebbeca A. Gallun, Fundamentals of Oil \& Gas Accounting ( $\left(^{\text {th }}\right.$ edn Penwell, Tulsa 2008) 465.

${ }^{2}$ A public company might have other priorities such as domestic market, social policies, energy security, among others.

${ }^{3}$ This area is known as pre-salt because the oil reserves are located below the salt layer. This area covers the offshore coast of the states of Sao Paulo, Rio de Janeiro and Espirito Santo, but could be even larger.

${ }^{4}$ For further information: http://oilprice.com/Energy/Crude-Oil/Extreme-Offshore-The-Hunt-for-Hardto-Find-Crude.html.

${ }^{5}$ Petrobras is a Brazilian company with governmental and private capital. The government has a controlling number of shares but it is also listed in Brazil and New York.

${ }^{6}$ For further information: http://www.ft.com/cms/s/0/ad7dc7c6-b4c3-11e0-a21d-00144feabdc0.html\#axzzliKBvMiFx.

${ }^{7}$ For the purposes of this paper JV has the same meaning as Joint Operating Agreement (JOA).
} 
venture $^{8}$ and it is essential for each party to pay its share of the costs. ${ }^{9}$ On occasion, however, a consortium member may not be able to pay or may simply choose not to. If enough participants fail to meet their commitments the eventual result will be the loss of the petroleum title. $^{10}$

In the petroleum industry the main deterrence to such behaviour is the threat that investors will lose their assets. In some situations this threat, when it is enforceable, manages to hold a joint venture's members together. But in other circumstances, it can have the opposite effect: a JOA party may default as a way of escaping from its commitments to an unsuccessful exploration program, for instance, or may wish to withdraw from a project near to the end of its life when decommissioning costs are due to be paid. ${ }^{11}$

The principal question considered in this paper is: how can companies protect themselves against the problems created by the default of another participant in a long term petroleum joint venture. $^{12}$

Historically, oil and gas investors have generally taken the view that, in a joint venture, provision against default was not needed. ${ }^{13}$ Before the 1970 s it was not unusual to find JOAs

\footnotetext{
${ }^{8}$ See: Chris Wilkinson, Joint Ventures \& Shareholder's Agreements $\left(3^{\text {rd }}\right.$ edn Bloomsbury Professional, West Sussex 2009) 3-5 and Gerard M. D. Bean, Fiduciary relationships, fiduciary duties and joint ventures: the joint operating agreement (University of Cambridge, Cambridge 1992) 19.

9 Bernard. G. Taverne, Co-Operative Agreements in the Extractive Petroleum Industry (Kluwer Law International, The Hague 1996) 55.

${ }^{10}$ Anthony Jennings, Oil and Gas Exploration Contracts (2 ${ }^{\text {nd }}$ edn Sweet \& Maxwell, London 2008) 25.

${ }^{11}$ Charez Golvala, 'Upstream joint ventures - bidding and operating agreements` in Geoffrey Picton-Turbervill (ed.), Oil and Gas: A practical handbook (Global Law and Business, London 2009) 50.

12 Sandy Shaw, 'Joint Operating Agreements ' in Martyn R. David, Upstream Oil and Gas Agreements (Sweet and Maxwell, London 1996) 24-25.

13 "Beyond debating the number of grace days and the appropriate rate of interest, neither the consortium members nor their lawyers appeared to give much thought to the provision [ie default]. Closer scrutiny of the default provisions came only after the first commercial oil fields has been found and the consortium members committed themselves to the enormous expenditures required to develop the discoveries. Even then the scrutiny came more from the banks seeking to finance the developments than from the consortium members themselves". D. M. Willoughby, Forfeiture of Interests in Joint Operating Agreements (1985) 3 J. Energy \& Nat. Resources L. 256.
} 
established without any such provision. Instead, there was a strong implicit and felt obligation for a company to be a 'good' fellow member of the consortium. If it could not play the game (that is, pay its share of the bills) it should not be in the industry. ${ }^{14}$ In other words, there was an assumption of mutual good faith among the members of a joint venture; it was accepted that the solvency of each member promoted the reputation of the whole group. ${ }^{15}$ And reputation was a major asset.

This 'golden age', however, ended some time ago. Companies in JOAs are now much more likely than they were to suspect their fellow JOA members of being future defaulters and to foresee possible financial problems during the life of the JOA. While there is not enough data to estimate the number of defaults which actually take place, there is an ever-greater increase in the size and difficulty of investments along with changes in the size and nature of companies. Hence there can be little doubt that the problem of default is on the increase. Partly this is because of changes in the industry. Changes in regulatory rules over such questions as decommissioning of oil and gas infrastructures are factors which can increase the pressures which might end in default. These and other objective changes are causing companies participating in joint ventures to feel a growing need for a protective mechanism against default by their partners.

A first thing a JOA participant company is to make its own rigorous analyses of the financial strengths of each participant before any agreement is signed. ${ }^{16}$ Oil and gas companies now as a matter of best practices make a preliminary financial analysis of their potential partners before signing a joint venture with another company. But once the venture is signed, the default issue is often set aside, to be regarded as no more than one risk of the project among others. Some companies even deal with the problem by conducting all upstream activities in a single enterprise instead of a joint venture so as to avoid all consortium-related pitfalls. ${ }^{17}$ But neither of these approaches resolves the central question of default risk and how to

\footnotetext{
${ }^{14}$ Chris Thorpe, Fundamentals of Upstream Petroleum Agreements (CP Thorpe, UK 2008) 141.

${ }^{15}$ Ibid.

${ }^{16}$ Scott Styles, 'Joint Operating Agreements' in John Paterson, Greg Gordon (eds), Oil and Gas Law: Current Practice and Emerging Trends (DUP, Dundee 2007) 289.

17 John Wilkinson, Introduction to Oil and Gas Joint Ventures (OPL, Ledbury 1997) 11.
} 
minimise it. The first virtually ignores default risk as a specific problem of joint ventures and the second eliminates participant risk by eliminating participants.

This research paper explores a range of possible solutions to the default risk problem as it appears in joint ventures in the petroleum industry. Most of these model solutions have been developed by industry associations, some of them from different regions, and in a few cases (for instance, Norway and Greenland) they have been devised by governments. The principal remedy employed in virtually all of these models is the partial or complete forfeiture of a defaulting party's interests in the project, or a variant of this mechanism (such as a withering, lien or buy-out); but these remedies are not sure ones and they often raise uncertainty about whether they are enforceable. But, even if they are, they can sometimes operate to the benefit of the defaulting party. The paper, therefore, examines possible alternatives to the solutions based on partial or complete forfeiture; these include collateral support provision, secured interests and cross-default options structured over wider asset interests.

The enforceability of default provisions is not dealt with in this paper. This is both because the issue is already adequately dealt with in several other publications and, more importantly, because the efficacy of the provision precedes its enforceability. ${ }^{18}$ If, as the paper argues, the default provision is not likely to be effective, then the question of its enforceability is redundant. Sections 2 and 3 of the paper describes what is accepted as best international practice around the world and sets out a detailed analysis of the main alternative practices. Section 2 also briefly describes the results of an empirical survey conducted by the author which confirms that actual practice in the industry closely reflects the emphases and measures seen in the more theoretical models. Section 4 analyses some additional concerns regarding the default mechanism. Section 5 sets out the recommendations which arise from

\footnotetext{
${ }^{18}$ R.W. Bentham, 'Joint operating agreements - default' (1990) 8(1) J.E.R.L. 63, Peter Roberts, 'Fault lines in the joint operating agreement: forfeiture' (2008) 7 I.E.L.R. 274-278, David Dawborn, John Waite, 'Contractual forfeiture of joint venture interests: are such clauses enforceable' (1990) 8 Oil \& Gas Law \& Taxation Review 389-392, Christopher Parr, 'Relief against forfeiture under joint operating agreements' (1986/87) 5(10)O.G.L.T.R. 253-255, Terence Daintith, Geoffrey Willoughby (eds), Adrian Hill, United Kingdom Oil \& Gas Law ( $3^{\text {rd }}$ edn Sweet \& Maxwell, London 2009) 1143-1150, Michael P. G. Taylor, Sally M. Tyne, Taylor and Winsor on Joint Operating Agreements ( $2^{\text {nd }}$ edn Longman, London 1992) 77-96, Peter Roberts, Joint Operating Agreements: A Practical Guide (Globe Law Business, London 2010) 185-204, Bernard Taverne, An introduction to the regulation of the petroleum industry: Law, Contracts and Conventions (Graham \& Trotman, London 1994) 138.
} 
this survey of theory and practice, particularly those concerning how to develop a safer financial relationship among members of long term petroleum joint ventures. 


\section{Default and the default provision}

2.1. The context of the petroleum industry

The default ${ }^{19}$ provision in the petroleum industry is a mechanism which aims to safeguard the financial resources of a venture so that it can execute its joint operations. In Taverne's words, 'Joint Operations shall be funded by the parties in proportion to their respective participating interests. ${ }^{20}$ If any party is unable to contribute according to its level of participation (its share of the costs of the joint operation) then the default ${ }^{21}$ provision will be triggered and a new sharing of costs must be established, since the activities cannot proceed without the financial means with which to cover all of the joint venture's financial obligations. ${ }^{22}$

Therefore, default is in the first instance the failure to pay on a due date; but more generally 'any shortfall or any delay in payment is [also] deemed to be a default. ${ }^{23}$ If the defaulting party cannot remedy its default, then it will increase the costs and expenditures of the nondefaulting parties. Avoidance of this is the primary reason why the JOA parties pooled their efforts by forming a single venture in the first place. ${ }^{24}$ In other words, the default provision in JOAs is not just a mechanism to ensure the payment of a particular amount of money, but rather a provision which is essential to the continued existence of a consortium. ${ }^{25}$

Prior to the 1970s it was not uncommon to find JOAs without any explicit measures to deal with default provision. Most companies were sufficiently deterred from default by the unacceptable blow it would have meant to their reputation. In later years JOAs started to place specific default provisions in their agreements, but still less as a guide about what to do

\footnotetext{
${ }^{19}$ Bill Manning (n. 1) 339.

${ }^{20}$ Bernard Taverne (n. 18) 138.

21 'Where a party fails to meet a call [cash call] this is a default, and to protect the project often the JOA will provide that non-defaulting parties must make up the shortfall pro rata.' Gerard M. D. Bean (n.13) 17.

${ }^{22}$ Scott Styles (n.16) 289.

${ }^{23}$ Kenneth Charles Mildwaters, Joint Operating Agreements, A Consideration of Legal Aspects Relevant to Joint Operating Agreements used in Great Britain and Australia by Participants thereto to Regulate the Joint Undertaking of Exploration for Petroleum in Offshore Areas with Particular Reference to their Rights and Duties (PhD Thesis presented to the University of Dundee, 1990) 227.

${ }^{24}$ For example the Australian case Monarch Petroleum NL v Citco Australia Petroleum Ltd [1986] WAR 310.

${ }^{25}$ Michael Lishman, Penalties and Relief Against Forfeiture of Joint Venture Interests (2008) 27 ARELJ 226.
} 
after a default and more as a threat which would prevent the default from happening. These default provisions still did not give the impression that they were in normal circumstances designed to be used. Their real purpose was to act as a vague constant threat to those parties which failed to meet their financial commitments to the joint venture. It is fair to say that until the 1980s, JOA parties in general were not seriously concerned about defaults but rather with maintaining spotless financial reputations. Roberts describes the psychology behind the JOA party's views as follows:

The risk of a party's failure to meet its share of a cashcall or invoice request when due is ever-present within any JOA relationship. Historically, the greatest mitigant of this risk has been a combination of the operational sociology and the commercial logic of the JOA - that the parties to the JOA have been solvent and able to meet all of their cashcall or invoice request commitments; that the character of each party is such that it would do nothing to incur the reputational risk associated with becoming known as a defaulter; and that the parties have had an obvious commercial interest in maintaining their interest in a concession (and a JOA) which relates to a project which has significant prospectivity associated with it. Because of the existence of these factors, the remedies contained in the JOA which would be applied to a party's default, while important to have in place, have typically played a secondary role in keeping the JOA relationship on track.

It has been an article of faith in operation of the JOA that the threat to a defaulting party of the loss by forfeiture (at least in part, and possibly completely) of its interests, and the reputational damage generally be sufficient to prevent the failure of a party to pay its share of a cashcall or of an invoice request when due. This has not been an unreasonable expectation, but any change for the worse in the character of the parties to the JOA should necessitate a re-evaluation of this assumption. It may be that a potentially defaulting party might be unconcerned by such a risk forfeiture, especially where the JOA (and particularly the implication of the attendant decommissioning costs liability) is proving to be more of a liability than an asset. ${ }^{26}$

Since it was so rarely used in practice, the JOA default provision has not been well explored or tested in the courts - a point recognized by several authors, including Jennings ${ }^{27}$ and Shaw. ${ }^{28}$ Daintith puts the question in a clear historical context when he writes that:

\footnotetext{
${ }^{26}$ Peter Roberts (n.18) 202.

27 'There is rarely a default by a participant in the payment of its share of expenditure but it is not unknown.' Anthony Jennings (n.10) 25.

28 'Default in payment is actually quite rare, other than short term errors in administration or disputes between the parties on specific billings.' Sandy Shaw (n.12) 25.
} 
The question of enforceability of forfeiture provisions in JOAs has arisen in other jurisdictions, notably Australia, where they have been upheld in the exploration phase. There is a lack of English or Scottish authority, largely because the operation of the default provisions has been extremely rare. The rarity can be explained by several factors: the uncertainty over relief against forfeiture itself operates, as the provisions are intended to do, as a deterrent to default; default endears the defaulter neither to the DECC nor to potential future co-venturers; the long planning periods in the UKCS usually allow sufficient time for companies to resolve any problems in advance, whether by farmout or outright sale of an interest or by rearranging financing; the 60 day period commonly allowed to remedy default is sufficient time for companies or their backers to sort out the financial position in the case of default; and co-venturers dislike default and are consequently usually inclined to assist companies to resolve their problems. ${ }^{29}$

Therefore, default has not been a common feature in the past. In several parts of the world, however, the situation has already changed as the major players have been replaced by smaller, independent ones, often with investments particularly concentrated in mature provinces. This is quite natural as major companies prefer a larger scale of investment looking for equivalently higher potential profits even though the risks are greater. The recent migration by IOCs from the UK continental shelf (UKCS) to elsewhere (Brazil, Angola, Nigeria, Iraq) is a good example of this trend. ${ }^{30}$

Although several courts (in England, Scotland and Brazil, for instance) ${ }^{31}$ are unfamiliar with oil and gas default provisions, other judicial systems (including the American, Canadian and Australian) are far more accustomed to them. ${ }^{32}$ The reason is simply that these latter jurisdictions have a tradition of attracting smaller and independent players. Their approach is quite different to the traditional one of a petroleum industry dominated by major international oil companies (IOCs) and national oil companies (NOCs).

\footnotetext{
${ }^{29}$ Terence Daintith,(n.18) 1182/2-1182/3.
}

${ }^{30}$ Scott Styles (n.16) 289 and Chris Thorpe (n.14) 14.

${ }^{31}$ Chris Thorpe (n.14) 289.

${ }^{32}$ See: Mocais Oil NL v Angari Pty Ltd (No. 2) Supreme Court of New South Wales [1990] 8 ACLC 780, Wetter v New Pacalta Oils 2 W.W.R. (NS) 290 (Alberta), Ernest E. Smith, 'Joint Operating Agreement Jurisprudence ' (1994) 33 Washburn Law Journal 834, Hew Dundas, 'Joint Operating Agreements: An Introduction` (1994 Summer Programme: UK Oil and Gas Law, CPMLP 09/09, 1994) 12-14. 
What makes it important to examine the default provision today, therefore, is that it is likely to be used much more often than in the past. Although a default affects all the parties in a JOA, historically the non-operators are less likely to enforce the application of a default provision than operators. Dundas and Daintith recognise the greater likelihood of nonoperators breaching the default provision when they suggest that:

This may be one of the most vital of the JOA clauses, the reason for its existence being that, where one of the non-operators fails to meet his share of a cash call made under the JOA, Operator would not be sufficiently funded to meet joint venture commitments, with potentially serious consequences for the progress of the joint operations. $^{33}$

To avoid the operator having to shoulder the unfair burden of funding the default, the JOA will normally provide that in the event of default by one or more of the parties the operator may issue additional cash calls to the non-defaulters calling upon them to make up, in proportion to their respective percentage interests, the amount in default. $^{34}$ (emphasis added)

The default provision, however, applies not only to non-operators but to all parties involved, including the operator. To deal with an operator's default, the non-operators need some additional precautions since it might be difficult even to find out that an operator's default had taken place. The JOA could stipulate, for instance, that the operator has an obligation to prove, on a regular basis, that it is carrying out its funding obligations. ${ }^{35}$

The JOA approach, that a party is regarded as being in default as soon as it fails to a make a payment due to the consortium, is common to the whole petroleum industry. ${ }^{36}$ but the way that the provision is implemented can vary from one JOA to another. ${ }^{37}$

\footnotetext{
${ }^{33}$ Hew Dundas (n.32) 12.

${ }^{34}$ Terence Daintith (n.18) 1147.

35 Ibid 189.

${ }^{36}$ See: Michael Taylor (n.18) 77, Sandy Shaw (n.12) 25, Bernard Taverne (n.18) 141, Chris Thorpe (n.14), Charez Golvala (n.11) 49-51, Claude Duval and others, International Petroleum and Exploration Agreements: Legal, Economic \& Policy Aspects (2 ${ }^{\text {nd }}$ edn Barrows, New York 2009) 299, Anthony Jennings (n.9) 25.

37 'If a party fails to transmit in full the funds required to meet an invoice on the due date, it is said to be in default. This sets in train a sequence of events that will result, if the defaulter does not come up with the money and cure the default, in the forfeiture of its entire participating interest without compensation. The details may differ, but the scheme is essentially the same in every JOA.' Chris Thorpe (n.14) 139-140.
} 
The parties must decide which of the possible variant models should actually be applied in their particular JOA, the commonest one traditionally being the forfeiture provision. Of the more than 60 signed agreements examined by the author, covering the years 1965 to the present day, almost all relied explicitly on a forfeiture mechanism to secure payments and the remaining ones use a variant or variants of forfeiture, such as buyout, withering, lien or a mortgage mechanism. More details are provided on these concrete agreements in Section 2.3 and some of the mentioned variants of forfeiture will be explained in Section 3.

A strict forfeiture provision means that as soon as a default is fully confirmed, the defaulting party loses all of its rights to participate in the consortium. This is without question the commonest mechanism used to deal with the default provision in the petroleum industry. But it arouses two particular concerns: first, that it may be difficult to enforce (a topic outside the scope of this paper) and second that it may be ineffective, a question which will be analysed in this paper. Meanwhile, there are a significant number of variants of the forfeiture mechanisms which exist in the petroleum industry, some of which have less irrevocable consequences than mentioned above. One such example, known as 'Withering Interest', allows the defaulting party to suffer only partial forfeiture, proportionate to the extent of its default. ${ }^{38}$ Although the penalty is thereby reduced, ${ }^{39}$ concern is still expressed that the way the formula is calculated may give too much power to either the defaulting or the nondefaulting party. ${ }^{40}$ The complexity of designing a provision which satisfies both parties is an obstacle to using this alternative way of managing default. ${ }^{41}$

\footnotetext{
${ }^{38}$ 'Withering appeared in the 1970 s when smaller companies became concerned for that some reason or other they could be manoueuvred into default; the clause operates to the effect that the defaulter does not lose his entire interest but can retain a reduced one, typically calculated on the basis of his total monetary contributions related to the total joint venture costs. The advantage is that there is less chance of such provision being regarded as a penalty clause.' Ibid.

${ }^{39}$ 'If, as argued above, the danger of a provision for outright forfeiture being held to be a penalty is minimal, the complexities and potential disavantages of the withering clause are probably best avoided unless, as in the mid1970s, commercial factors impel parties to argue forcibly for its adoption rather than forfeiture.' Michael Taylor (n.18).

${ }^{40}$ Peter Roberts (n.18) 198.

${ }^{41}$ Scott Styles (n.16) 289.
} 
Another variation of forfeiture is the buy-out mechanism. This is reasonably balanced ${ }^{42}$ between the parties as it guarantees to a defaulter fair compensation for its past contributions and other forms of participation during the existence of the consortium ${ }^{43}$. A buy-out option might be exercised internally (among the existing JOA parties) or externally (by third parties entering the agreement). ${ }^{44}$ The most difficult aspect of the buy-out option is 'how to arrive at a method of valuing the defaulter's interest which is simple and swift to operate and acceptable to all parties'. ${ }^{45}$ This means that the parties must exercise great care in devising a suitable mathematical formula to determine the value of the buy-out option. If this is not done, buy-out will suffer the same problems as forfeiture in most of its other forms.

While total forfeiture is by far the most common alternative chosen by the JOA parties, each instance requires the drawing up of a very detailed procedure regarding the application of the default mechanism. ${ }^{46}$ Initially, the JOA is required to present a notice and there will be a certain period of time (commonly 6 to 12 days) ${ }^{47}$ for the defaulting party to remedy its failure by contributing to the relevant cash call. Meanwhile a defaulting party will suffer some restrictions on its rights under the JOA: its right to obtain information, to vote in the Opcom, to take its production share ${ }^{48}$ and to transfer its interest, among others. ${ }^{49}$ If the defaulting party does not remedy the default within a further period of time (commonly 60 days) the

\footnotetext{
42 "The "purchase price" clause, common in Australia and New Zealand, is based on the assumption that the non-defaulters are obligated to pay the defaulter the purchase price of his percentage interest, net of sums in default.' Hew Dundas (n.32) 15.

${ }^{43}$ G. Willoughby describes the lack of fairness of forfeiture as he states that 'It had the usual default clause, which did not differentiate between the various stages of the venture, and it was not until the field came to be developed in 1975-1976 that the adequacy of the provision was questioned.' G. D. M. Willoughby, 'Forfeiture of Interests in Joint Operating Agreements' (1985) 3 J. Energy \& Nat. Resources L. 257-258.

${ }^{44}$ 'Rather than have a sale of the defaulting party's interest to the non-defaulting parties, the JOA might require a forced sale of the defaulting party's interest on the open market.' Peter Roberts (n.18) 198.

${ }^{45}$ Ibid 198.

${ }^{46}$ Scott Styles (n.16) 289.

${ }^{47}$ Ibid.
}

48 As previously mentioned, the non-defaulting parties might be able to market such production to cover the respective fault. This procedure 'represents a limited departure from the customary reluctance of the JOA to endorse joint sales of petroleum.' Peter Roberts (n.18) 191. The risk of such approach is the connection with partnership requirements under Partnership Act 1890 (UKCS).

${ }^{49}$ Peter Roberts (n.18) 190. 
non-defaulting parties can take possession of the interests of the defaulting party in the venture.

The non-defaulting parties then have an obligation to cover the share of the defaulting party or else they will also be in default. ${ }^{50}$ It is not fair, however, to deal in exactly the same way with the original defaulter as with the subsequent defaulter whose new liabilities were not predictable when the JOA was executed. Although it might seem unfair to enforce the obligation to cover someone else's expense, this is necessary to maintain the existence of the consortium, otherwise termination would be the only solution.

Sometimes non-defaulting parties can opt not to exercise the forfeiture provision but instead to perform the joint operations without the participation of the defaulter. The effectiveness of this alternative procedure relies on the JOA imposing restrictions upon the defaulting party's rights (such as to receive information or participate in the Operating Committee). ${ }^{51}$ Daintith is referring to this alternative when he states that 'it is envisaged that in some circumstances, the non-defaulters may prefer not to enforce the forfeiture option, but simply to continue operations without the defaulter' ${ }^{52}$ But this alternative will not by itself solve the cash contribution requirement and it might even create additional problems, such as that the assignment of the petroleum title might be impossible without the consent of all parties. ${ }^{53}$

As a result of some of the problems mentioned above the default provision can pose a real threat to the parties of a JOA, as can the sole risk provision (that is, the possibility of proceeding with an exclusive rather than a joint operation). Either of these procedures can have a quite severe impact on the defaulting or non-sole risk party. In other words, the negative consequences of these provisions are designed to deter either a failure of cash

\footnotetext{
${ }^{50}$ Terence Daintith (n.18) 188.

${ }^{51}$ The main operational restriction is the right to vote in the Opcom. Peter Roberts describes this situation in the following terms 'Where the voting rights of the defaulting party have been suspended for so long as the default continues unremedied, the voting interest of each non-defaulting party will be set pro rata to the proportion which each non-defaulting party's PI bears to the aggregate of all the non-defaulting parties' PIs.' Peter Roberts (n.18) 190-191.

${ }^{52}$ Terence Daintith (n.18) 1149.

${ }^{53}$ Ibid.
} 
contributions or a withdrawal from the joint operation since the final result will be the same in both cases (namely, the end of the consortium). ${ }^{54}$

Murphy describes the mentality behind the harshness of the provisions to deter possible defaults:

When the drafting committee of the Association of International Petroleum Negotiators ("AIPN") first drafted the 1990 Model Form Joint Operating Agreement and later the 1995 Model Form ("JOA"), many participants wanted to be as hard on a defaulting party as possible. Basically, they wanted to "punish" a defaulting party beyond the limits of reason. It almost became a contest to see who could put the most onerous default provision in its agreement to ensure it would be paid before another venture would be paid. The drafting committee decided to include in the JOA a "default" clause (Article 8) which provided, among other things, that a defaulting party would forfeit its participating interest under the JOA if it failed to pay its invoices in a timely manner. ${ }^{55}$

Although harsh measures might secure a higher level of commitment from all the parties (due for example, to high expected prospects during exploration phase, or highly profitable production), there are uncertainties under general law (especially common law) about whether such forfeiture provisions could face problems of enforceability, either because they could be considered a penalty or because of conflict with the insolvency laws. ${ }^{56}$ Academics and practicing lawyers have given much more attention to the penalty question since it is something which every default provision will face. The insolvency is less analysed since is something which may or may not arise. However, both issues are outside the scope of this paper and there are a large number of publications which deal with them.

Decommissioning obligations are a further possible problem in a default. If the default occurs at the beginning of the life of the consortium, this is unlikely to be serious for the joint venture since the production revenues will cover decommissioning costs. Taverne has made the following comment: 'As long as a defaulting party remains in default it is no longer

\footnotetext{
${ }^{54}$ Chris Thorpe (n.14) 140.

${ }^{55}$ P. Sean Murphy, Read The Contract You Thought You Made: The Express Negligence Doctrine (Part 1). See: http://library.findlaw.com/2003/Feb/24/132507.html.

${ }^{56}$ Scott Styles (n.16) 289.
} 
entitled to receive its share of the petroleum production: this share will be taken by the operator and distributed among the non-defaulting parties'.57

Decommissioning during the final stages of a development, however, may be a more serious problem since the petroleum title may have been converted from an asset into a burden, as the decommissioning costs overtake the value of the remaining production. ${ }^{58}$ Shaw describes this situation in the following terms:

In any event, the question of liability for abandonment remains: it should not be open to a party to withdraw from the JOA by way of defaulting on its obligations and escape abandonment liability. Modern JOA's usually provide for this ongoing liability, much the same as in the withdrawal provisions.

In other words, a defaulting party may be happy to be losing its participating interest if the liabilities are greater than the value of the assets. If there is no decommissioning arrangement in place, ${ }^{60}$ then the parties should take additional care before drafting the default provisions.

A similar situation can arise with regard to default during an unsuccessful exploration operation (for instance, a 'dry hole') where there is no production ${ }^{61}$ to compensate for the 'failure of cash performance'. Manning states that:

It has been said that forfeiture is really only appropriate when the exploration joint venture is at the "grass roots" stage, that is, when no resource has been discovered upon which any value could be placed. In that situation, the acquisition of an additional interest by forfeiture can be seen as the assumption by the other participants of additional obligations under the terms of the tenement and the joint venture agreement rather than the loss of an asset by the defaulting participant. ${ }^{62}$

\footnotetext{
${ }^{57}$ Bernard Taverne (n.18) 141.

${ }^{58}$ Peter Roberts (n. 18) 186, Scott Styles (n.16) 289 and Charez Golvala (n.11) 50

${ }^{59}$ Sandy Shaw (n.12) 25.

${ }^{60}$ ‘ $(\ldots)$ it is essential that detailed provisions governing security for the costs of decommissioning are negotiated far enough ahead of the point at which a field becomes uneconomic for any party, so that the party does not preempt its abandonment obligations crystallising by withdrawing early from the venture.' Charez Golvala (n.11) 50 .

${ }^{61}$ 'It is worth remembering that forfeiture of production is only of value to the parties where the asset is producing (...)'. Sandy Shaw (n.12) 26.

${ }^{62}$ Bill Manning (n.1) 339.
} 
The acquisition of a defaulter's interest is not seen as being beneficial in the exploration stage of a venture. On the contrary, it involves an additional financial commitment without necessarily any return. If there is eventually any return, it will frequently only be revealed after the expenditure of further funds to which the defaulting party should have contributed, but to which it did not contribute. ${ }^{63}$

As a result of these problems, the forfeiture mechanism might not be as effective a threat as most people might think. It has value only if the defaulting party's assets are worth significantly more than the amount of the default. This difference is strongly influenced by the stage which the petroleum production project has reached. High value assets are most likely to be found in the middle stages. So, while there are some periods in the lifetime of a project when it might be said that something is better than nothing, at other times the default provision will be completely or at least largely irrelevant. ${ }^{64}$

\footnotetext{
${ }^{63}$ Ibid 340.

${ }^{64}$ Ibid.
} 


\subsection{International Standard Practice}

In order to understand the nature and efficacy of current practice regarding default provisions in the petroleum industry we need to see how they are presently drawn up and applied by the main actors in different parts of the world.

This section of the study, therefore, will describe and comment on the most widely-used JOA standard model forms. These are produced by industry associations (except the Norwegian and Greenlandian models) and are mostly designed to be used under different judicial systems. But joint ventures are entitled to draw up their own rules and are not for the most part bound by any of these model agreements. This section will describe eight different models (presented in order of their first use): (i) the American Association of Professional Landmen (AAPL) Model (the 'first American Model'), (ii) the Rocky Mineral Mountain Law Foundation (RMMLF) Model (the 'second American model'), (iii) the Canadian Association of Petroleum Landmen (CAPL) Model (the Canadian Model), (iv) the Oil and Gas United Kingdom (OGUK) Model (the British model), (v) the Norwegian model, (vi) the Australian Mineral and Petroleum Law Association (AMPLA) Model (the Australian model). (vii) The Association of International Petroleum Negotiators (AIPN) Model (the International model) and (viii) the Greenlandic model.

\section{AAPL JOA Model (the first American model)}

The AAPL has produced a number of different versions of its JOA during recent decades. Of these the most important are Form 610 (dating from the 1950s), which applies to onshore projects, and Form 810 (dating from the 2000s), a newer version which deals more with offshore projects.

Form 810 outlines its default provision not in the model itself but in an attachment to it. This approach is not common among JOAs and is perhaps surprising given that the financial contribution is the most important issue for the consortium, because the sharing of costs and risks are the essence of the JOA.

Under this provision if a party fails to pay its cash call contributions, then the operator will issue a default notice to that party which must remedy the situation within 30 days, Once 
default is established then, until a remedy is provided, the defaulting party will lose most of its rights, crucially the rights to vote and to obtain information. If a proposal of work is made during this defaulting period, then the defaulter must be considered a non-consenting party, unless the agreement makes it compulsory to maintain all the parties in the consortium. ${ }^{65}$ If no payment is made for a period of 60 days more severe action can be taken by the nondefaulting parties.

The AAPL Form 810 does not strictly provide for a forfeiture provision but rather an encumbrance over each party's participating interest. The non-operators issue a mortgage or a similar mechanism over their participating interest, and any production and property participation related to the consortium, in favour of the Operator. The operator in turn, grants a mortgage and security interest over the same things in favour of the Non-Operators. In short, if there is a default, then the other parties can 'remove' the property from the defaulting party in order to guarantee the payments due from the consortium. ${ }^{66}$ In addition, all parties provide reciprocal power of attorney for all participants so as to guarantee payment of the applicable security interest. ${ }^{67}$

This suggests that the AAPL Form 810 avoids strict forfeiture solutions by substituting this mechanism of mutual security interests. To be effective, however, such a solution must comply with the prevailing legislation and also with the title to the petroleum. Even then, the solution might only work during the development or production phase, since in later phases the participating interest might have no, or insufficient, remaining value, or there might be no production or property available to secure the costs. Finally, the form does not address the issue of on-going liabilities related to the interest of the defaulting party.

The historical AAPL Form 610 adopts a similar approach to that of Form 810, preferring more burdensome encumbrances to a strict forfeiture under which the defaulting party retains more rights. The most interesting element of this model is the creation of a lien of each party's participating interest in favour of the other parties. ${ }^{68}$ This means that if any party fails to

\footnotetext{
${ }^{65}$ AAPL JOA Model Form 810 Attachment F $§ 6.3$ (b).

${ }^{66}$ AAPL JOA Model Form 810 Attachment F $§ 6.3$ (a).

${ }^{67}$ AAPL JOA Model Form 810 Attachment F $§ 6.3$ (c).

${ }^{68}$ AAPL JOA Model form 610 Article VII (B).
} 
contribute towards the joint expenditure then its participating interest in the consortium and any other property related to the consortium will secure such payments. This might require registration within a certain period of time otherwise it will not be enforceable.

Clear provisions are included about the norms regarding the use of power of attorney by the non-defaulting parties to execute operations or even to sell the defaulting party's property related to the consortium. ${ }^{69}$ This is a valuable way of avoiding delays if the defaulting party refuses to sign the required documents.

This Form 610 follows a fairly standard procedure to establish a default. ${ }^{70}$ First, the operator must give notice of the existence of the breach. ${ }^{71}$ The non-operators also need to secure reciprocal provisions to deal with the unlikely event that the operator infringes them. After the notice is posted, the defaulting party has 30 days to cure the situation, otherwise that party will be definitively in default. The suspension of rights will continue until a cure is fully provided and until that time the defaulting party will be considered a non-consenting party for any proposal of work. ${ }^{72}$ If the operator is the defaulting party, then the non-operators have the right to vote and to nominate a new operator, if a determined percentage of them so decide (the so-called pass mark). ${ }^{73}$ If the defaulting party does not cure the default within 120 days from the issuance of the default notice, then the non-defaulting parties might execute the lien and the defaulting party must forfeit its interest in the venture to the value of the default. ${ }^{74}$

It can be argued that the historical 610 model form provides a balanced provision because it clearly takes a neutral approach with regard to the procedures involving the default: in some circumstances it becomes reciprocal and could be applied by non-operators to the operator. The implementation of lien (the right to take possession of the PI or property of a defaulting party) and the power of attorney is an effective way to secure the payment of the relevant

\footnotetext{
${ }^{69}$ AAPL JOA Model form 610 Article VII (B).

${ }^{70}$ AAPL JOA Model form 610 Article VII (D).

${ }^{71}$ AAPL JOA Model form 610 Article VII (D)(1).

${ }^{72}$ AAPL JOA Model form 610 Article VII (D)(1) (2).

${ }^{73}$ AAPL JOA Model form 610 Article VII (D)(1).

${ }^{74}$ AAPL JOA Model form 610 Article VII (B).
} 
expenditure (although it needs to be verified whether a lien conflicts with any local laws in order for it to be enforceable). On the other hand, this form does not address the potential issue of decommissioning costs or exploration costs where the lien is not going to give any assistance at all since the defaulter has no property of value to be confiscated. Finally, this historical model is also balanced in another way since it provides a reasonable amount of time for the defaulting party to cure its default.

In conclusion, the AAPL model avoids the strict forfeiture solution for default by imposing restrictions over the participating interest and related rights of the defaulter in the form of a security (in other words, guarantee) for the payment of the required expenditures in the JV. Local laws, however, as well as any restrictions on the title to the petroleum, must be taken into account or else the proposed solution will be ineffective. The major flaws in the AAPL JOA model forms are the failure to address on-going liabilities related to the default through the reliance on the market value of the participating interest or of any production or joint property which is available. The assets which can in principle act as the security interest cannot in practice do so if they lack present market value.

\section{RMMLF JOA Model (the Second American Model)}

The RMMLF JOA model provides the shortest default provision of all the JOA models. There is no provision for any procedure involving default, aside from the creation of reciprocal liens among the JOA parties over their participating interest, property and share of production. ${ }^{75}$ This is probably the best scenario for the non-defaulting parties because they can simply determine the procedures applicable to the default. A defaulting party on the other hand is in a critical situation with such an uncontrolled approach, since it may not be granted enough time to remedy the problem even when, with more time, it might be able to raise the resources to do so.

This simple regulation, however, contains several flaws. First, it is an approach which might work at a stage in the development of a project when production is available but is much less likely to be effective during the non-productive stage. Second, there is no power of attorney so the non-defaulting parties might have problems enforcing their lien. Third, there is no

\footnotetext{
${ }^{75}$ RMMLF JOA $\S 4.7$.
} 
provision concerning decommissioning obligations. Fourth, there is no clear provision for suspension of the defaulting parties' rights under the JOA. As a result, the defaulting party maintains its right to receive information and to participate in proposals of work.

It seems therefore that in this approach, as opposed to other models, there are benefits and drawbacks for all parties. Non-defaulting parties have far more discretion to determine the procedures involved. These must, however, be reasonable and not too extreme; otherwise it may be possible for the defaulting party to obtain court relief. The defaulting party has little control over the situation, but nonetheless maintains most of its rights in the JOA.

\section{CAPL Operating Procedures Model (the Canadian model)}

The Canadian OP Model is based on an approach which is clearly different from that of the other JOAs. It grants authority to the Operator to request from each of the other parties, and in a manner which is satisfactory to the Operator, proof that each of them has sufficient financial resources to carry out the approved programme of the JOA.

This approach is clearly spelled out in the regulations regarding " Security for Payment':

(a) the Operator may, by notice, require a Non-Operator to secure payments of its Working Interest share of costs for an approved Joint Operation in a manner satisfactory to the Operator, acting reasonably, if it reasonably believes that the Non-Operator may be unable to pay those costs as and when due hereunder;

(b) a Non-Operator that does not believe that this request is reasonable will notify the Operator of its objection, and those Parties will resolve the matter under the dispute resolution process in Article 21.00;

(c) that objecting Non-Operator is not required to comply with the Operator's request until a determination under Article 21.00 that the request was reasonable, subject to Paragraph 5.03(d) and provided that this does not otherwise affect its obligation under the Accounting Procedure to pay amounts owing by it for that Joint Operation;

(d) that objecting Non-Operator requested to secure payment under this Subclause may not dispute the request under this Subclause and Article 21.00 if that Non-Operator: (i) has been placed into bankruptcy or receivership; (ii) is then subject to debtor relief protection under the Bankruptcy and Insolvency Act (Canada), the Companies' Creditors Arrangement Act (Canada) or similar Regulations; or (iii) has been served a bona fide notice of default under Subclause 5.05B during the preceding 6 months, and 
(e) a Non-Operator that secures payment under this Subclause through an irrevocable stanby letter of credit will establish it in favour of the Operator with a Canadian chartered bank. The Operator may then draw on the letter of credit on the same basis as in Subclause 5.03A or on such other basis as is provided in this Agreement for amounts to be paid with respect to a Joint Operation. ${ }^{76}$

This is probably the most innovative of all the standard JOA default mechanisms discussed in this paper. But it is by no means free of ambiguities. The non-operators can, for example, refuse to provide the security demanded if they believe it to be unreasonable. If they do refuse then the parties have to resolve this issue by dispute resolution. But the provision does not work in reverse: there is no obligation upon the operator to demonstrate its financial resources to the non-operators.

In case of a default the operator has to issue a default notice to the defaulting party and provide a copy for the other parties but only for informational purposes. ${ }^{77}$ If the defaulting party does not cure such a default within 5 days, then there it suffers several consequences: ${ }^{78}$ first, it has to pay interest on the sum defaulted; second, it loses its right to receive JOA information; third, it is not permitted to participate in any of the consortium's activities. If the default persists for more than 30 days, then the defaulting party will also lose its production share to the other parties and its rights over joint property. Finally, if the default persists for more than 60 days, then the non-defaulting parties can take possession of part of the defaulter's PI and property, thus executing the lien that is established upon every party's PI. ${ }^{79}$ As with most JOAs, this default mechanism also acquires its force not by imposing measures which are in themselves especially restrictive but rather from their inexorably cumulative nature. They place an ever tighter noose around the neck of a defaulter. ${ }^{80}$ This model is based in general on the assumption that the defaulting party is a non-operator, but there is also a special provision relating to the case where the operator is the defaulting party. ${ }^{81}$

\footnotetext{
${ }^{76}$ CAPL OP $\S 5.03(\mathrm{C})$.

${ }^{77}$ CAPL OP $§ 5.05(\mathrm{~B})(\mathrm{g})$.

${ }^{78}$ CAPL OP $§ 5.05(\mathrm{~B})$.

${ }^{79}$ CAPL OP $§ 5.05$ (A) (B).

${ }^{80}$ CAPL OP $§ 5.05$ (D).

${ }^{81}$ CAPL OP $§ 5.05(\mathrm{G})$ and 5.06.
} 
This Canadian OP adopts an approach fairly similar to that of the American models in that they all avoid pure forfeiture and buy-out options but focus more on securities as methods of possessing part of or the complete participation interest (including all related rights) of the defaulter in the consortium. Among the weaknesses of this model is its failure to provide clear regulation of the on-going liabilities of the defaulting party (especially those related to decommissioning), as well as its reliance on the effectiveness of the lien, which is only of value as long as there are enough resources in the ground to be recovered.

\section{OGUK JOA Model (the British model)}

The British JOA Model Form has a wide definition of default, including not only any failure to contribute to a relevant cash call, but also failure of a party to implement a decommissioning security agreement. ${ }^{82}$ The duty to meet decommissioning obligations is emphasised in the UK, which is considered to be a mature province. ${ }^{83}$ Most of the operations will soon be moving towards the end of their production cycle and will therefore face decommissioning challenges.

Since the approach taken by the British model presumes that a non-operator is more likely to be in breach, it deals fully only with a default notice issued by the operator. ${ }^{84}$ Only at the end of the clause dealing with that is there a special paragraph to deal with a case where the operator is the defaulting party. ${ }^{85}$ If this does happen the operator's duties are to be assumed by the non-operator with the largest participating interest, for as long as the default persists.

If the non-defaulting party does not pay its share over the required cash call, then the operator must notify the other parties within 3 days. The non-defaulting parties then have a further 6 days to pay for their additional share, otherwise they will also be in default. ${ }^{86}$ The aim of this provision is to secure the good standing of the petroleum title since the activities cannot stop and wait for the default to be remedied. Interest on any money which has been borrowed

\footnotetext{
${ }^{82}$ OGUK JOA $\S 17.1$

${ }^{83}$ See notes 35 and 36.

${ }^{84}$ OGUK JOA $§ 17.1$

${ }^{85}$ OGUK JOA $\S 17.9$.

${ }^{86}$ OGUK JOA $\S 17.2$ (b) (c).
} 
interest should be paid at Libor plus two per cent (not very high by financial market standards). ${ }^{87}$

If the defaulting party does not cure the default within 6 days several consequences follow. First, the defaulting party loses its right to take its production share which can therefore be marketed by the non-defaulting parties in order to cover the payment of outstanding expenditures. ${ }^{88}$ Second, the defaulting party loses its right to vote in the Opcom. If any work proposal is submitted, then the defaulting party is considered a non-participant. If unanimous consent is required for any action, then the defaulting party is excluded. Third, the defaulting party must be bound by any decision of the Opcom. ${ }^{89}$ Fourth, the defaulting party loses its right to obtain access to information. ${ }^{90}$ Finally, the defaulter also loses its right to withdraw from the agreement and to transfer its participating interest (except to the extent explicitly permitted in the default provision). ${ }^{91}$

If, however, the default persists for more than a period of between 30 or 60 days (varying with the stage of the project), then the forfeiture mechanism will be an option available for the non-defaulting parties. This model form also addresses the case of repetitive defaults (defined as more than 60 days within twelve successive calendar months). ${ }^{92}$ In any case, until the default is solved, whether by payment of the default, or execution of the forfeiture provision, or a decision to abandon joint operations, all the operations should remain in full force..$^{93}$

The execution of the forfeiture provision is subject to several conditions, ${ }^{94}$ but the most important one relates to the consent of the governmental authorities. If the host government

\footnotetext{
${ }^{87}$ OGUK JOA $\S 17.2$ (a).

${ }^{88}$ OGUK JOA § 17.4.

${ }^{89}$ OGUK JOA § 17.5.1.

${ }^{90}$ OGUK JOA $\S 17.5 .2$.

${ }^{91}$ OGUK JOA $\S 17.5 .3$.

${ }^{92}$ OGUK JOA $\S 17.6 .1$.

${ }^{93}$ OGUK JOA $\S 17.6 .2$.

${ }^{94}$ OGUK JOA § 17.6.3.
} 
does not approve the forfeiture, then the non-defaulting parties will have to deal with an awkward situation since the defaulting party will maintain its interest in the petroleum title but not in the JOA. The most interesting element of this forfeiture provision, however, is that it allows for compensation if the consortium's development plan is already in operation and production has begun. ${ }^{95}$ This is a reasonable approach since it avoids the threat ('terrorem') of a full forfeiture after a major investment has been made. If the parties cannot reach an agreement for this compensation within 30 days of the forfeiture exercise, then any party in the consortium can refer the matter for an expert determination, a highly regulated procedure which is binding on the defaulting party. ${ }^{96}$ The non-defaulting parties, however, have the option to refuse the expert determination and withdraw from the agreement. If the compensation is agreed, it is deducted from all costs related to the default and a discount on the valuation is also provided in the final section of the forfeiture provision. This discount will have been previously determined by the parties during the negotiation stage of their JOA.

Normally, in the British model, the defaulting parties give power of attorney to the operator to perform all necessary actions provided in the default provision. ${ }^{97}$ Although the power of attorney is expressly given to the operator, there is also a provision that grants the same power to the non-operators, if the operator is the defaulting party. ${ }^{98}$

The British JOA Model Form seeks a balance between, on the one hand, fairness to the nondefaulting parties by not allowing compensation before a development plan has been approved, and establishment of a neutral determination of compensation after the development is approved. The decision of the expert is strictly binding on the defaulting party but less rigidly binding for the non-defaulting parties because they can elect to withdraw from the agreement. This model also gives unusually thorough attention to decommissioning issues, powers of attorney and governmental consent. Its main weakness, however, is the lack of security before the development stage since no production and no appropriate asset is available at that stage to cover costs.

\footnotetext{
${ }^{95}$ OGUK JOA $\S 17.7$.

${ }^{96}$ OGUK JOA § 17.7.1 to 17.7.11.

${ }^{97}$ OGUK JOA $\S 17.8$.

${ }^{98}$ OGUK JOA $\S 17.9$.
} 


\section{Norwegian JOA Model}

The Norwegian default clause adopts the majority of the key elements which are commonly found elsewhere, starting by defining default as a breach of financial commitment whjch it is the duty of the non-defaulting parties to cover. ${ }^{99}$

If the defaulting party has not cleared its default in 5 days to cure its default otherwise it suffers several restrictions of its rights, including those to receive information and to vote in the Opcom. But this model adopts a less standard approach to the question of proposed work by the consortium: the defaulting party in this case is bound by the decision of the remaining parties rather than being deemed to be in automatic non-consent. ${ }^{100}$

Another unusual requirement is that the Operator must inform the governmental authorities (the Ministry) of any default. ${ }^{101}$ Usually this is regarded as a private issue between the JOA parties. In the Norwegian case a NOC is quite likely to be a party to a JOA and, because of this, the government is keen to impose a higher level of control over the joint operations.

Five days after the default notice, the non-defaulting parties can possess the defaulting party's production to cover the applicable costs. And if the default persists for more than 3 months the non-defaulting parties can demand that the defaulting party transfer its share to them. The defaulting party will, however, be compensated for its investments, the value of which are deducted from the applicable contributions and costs. The maximum compensation is the book value of the investments. ${ }^{102}$

Most of the ongoing liabilities are transferred to the non-defaulting parties, although there may be differences between particular agreements about the amounts transferred. ${ }^{103}$ This means that the parties must draft the terms of assignment with great care so that the

\footnotetext{
${ }^{99}$ Norwegian JOA $\S 9.1$.

100 Norwegian JOA $§ 9.2$.

101 Norwegian JOA $§ 9.2$.

102 Norwegian JOA $§ 9.3$.

${ }^{103}$ Norwegian JOA § 9.4.
} 
defaulting party remains liable only for the unsettled issues at the time of the assignment. Norway, like the UK, is a mature province but in this case there is no special concern about decommissioning issues in the JOA, although there are references to potential guarantees for decommissioning costs before the completion of a withdrawal. ${ }^{104}$

The most exceptional provision of this JOA is referred to as 'penal interest', which is described as follows:

If a Party is in default of his obligation to make payments pursuant to Articles 7,8 or the preceding paragraph, he shall be charged a penal interest pursuant to Article 1.2.2 of Attachment B - Accounting Agreement. ${ }^{105}$

Under several common law jurisdictions this provision might be considered as a penalty and consequently dealt with by the courts. It is an additional burden on the defaulting party which may have to deal with the suspension of some of its rights and the assignment issue, at the same time as this 'penalty'. In other words, this approach is a step closer to a unenforceable penalty provision.

In brief, the Norwegian model represents a balanced version of the 'buy-out' option, in which the defaulting party does not suffer draconian punishment. It suffers, however, from a lack of clarity on a number of questions including the determination of unsettled liabilities, the likelihood of becoming an unenforceable penalty provision, and the implications for the suspension of the operator's rights under the JOA in case of an operators.

\section{AMPLA JVModel ${ }^{106}$ (the Australian model)}

The Australian JV model's default provision takes an explicitly neutral approach to the different JOA members. ${ }^{107}$ From the start the default notice can be issued by any party; it is not assumed that it will be exclusively (or even predominantly) by the operator. ${ }^{108}$

\footnotetext{
104 Norwegian JOA $\S$ 24.3. 2.4.3. The other Parties may require that a satisfactory guarantee be provided concerning a proportionate share of the joint venture's liability for decommissioning of facilities belonging to the joint venture at the time of withdrawal.

${ }^{105}$ Norwegian JOA $§ 9.1$.

${ }^{106}$ For a detailed analysis over the enforceability of the default provision under the AMPLA JV model see: Michael Lishman (n.25). It is also relevant to note that the AMPLA committee approved a JOA version in the end of 2011. However, this new agreement is a mixture of their JV for mining and a standard JOA. For the purposes of this paper there is no substantial change in the default provision as the issues raised in this paper are not addressed in the new version. Thus, this paper will analyse the features of a JV in comparison to a standard JOA.
} 
The defaulting party has 14 days to cure a breach or to pay compensation to the nondefaulting parties. If the compensation cannot be agreed between the parties during the 14day period, then the matter is referred to an expert to determine the amount. ${ }^{109}$ The Australian model approaches the position of the non-defaulting parties in a way which is different from any other model discussed in this paper in that they have a right rather than an obligation to cover the breach opened by the default. This is an approach which clearly benefits the nondefaulting parties, although, if they cannot cover the costs, this might jeopardize the joint operations. $^{110}$

The defaulting party has to pay its default plus any related costs caused to the other parties, as well as interest charged at a fixed rate on these payments. ${ }^{111}$ The default provision does not finish until the defaulting party covers all the related costs. However, there is an alternative solution for this problem, namely a 'buy-out'. The Australian JV model form provides for a buy-out option instead of strict forfeiture, so that the non-defaulting parties can acquire the participating interest of the defaulting party. Although there is no obligation to acquire the defaulter's PI, the parties cannot exercise such a right partially. ${ }^{112}$ It is an all or nothing option.

Under the buy-out option the value of the assets is assessed at market prices. ${ }^{113}$ Again if the parties cannot agree on a fair market price for the acquisition of the defaulter's participating interest within 14 days from the decision in favour of a buy-out, then the case has to be determined by an expert, ${ }^{114}$ who must reach a decision within 30 days of nomination. ${ }^{115}$ The

\footnotetext{
${ }^{107}$ AMPLA JV § 12.

${ }^{108}$ AMPLA JV $\S 12.1$ (a).

${ }^{109}$ AMPLA JV § 12.1 (b) (c).

${ }^{110}$ AMPLA JV $\S 12.2$.

${ }^{111}$ AMPLA JV § 12.3.

${ }^{112}$ AMPLA JV § 12.5.

${ }^{113}$ AMPLA JV § 13.

${ }^{114}$ AMPLA JV § 13.1 and 13.2.

${ }^{115}$ AMPLA JV § 13.2.
} 
expert can determine that the value of the PI is negative, but, if so, no payment will be required from the defaulting party. ${ }^{116}$ If the non-defaulting party does not agree to pay the price determined by the expert, then it can use the cross charge mechanism whereby each party establishes an encumbrance on its participation in favour of the others in order to secure their payments. ${ }^{117}$ The cross charge might be executed in a similar way to a forfeiture provision. ${ }^{118}$ However, the defaulting party is obliged to accept the amount determined by the expert. ${ }^{119}$ On the other hand, the assignment of the defaulter's participating interest releases the defaulting party from any liability related to the JOA, for example, decommissioning and past liabilities, but does not release him from maintaining the confidentiality of the agreement. ${ }^{120}$ In order to secure the execution of the default provision a power of attorney is provided to the non-defaulting parties until the default is cured by the defaulting party or acquired by the non-defaulting party. ${ }^{121}$

The agreement makes clear that nothing in it can prevent the use of a remedy provided by general law which can be a useful tool for both the defaulting and non-defaulting parties. ${ }^{122}$ For example, a defaulting party might seek relief against unfair determination of the buy-out value and a non-defaulting party might seek court protection to execute the terms of the agreement.

While the approach of the Australian JV seems similar to that of a standard JOA, it does have some peculiarities. First, there is no suspension of rights during the period of default. Second, the defaulting party is released from any liability related to its PI once the assignment is executed. Third, the form provides for an expert determination mechanism which is not fully binding on the parties. Fourth, the form does not compel the non-defaulting parties to cover

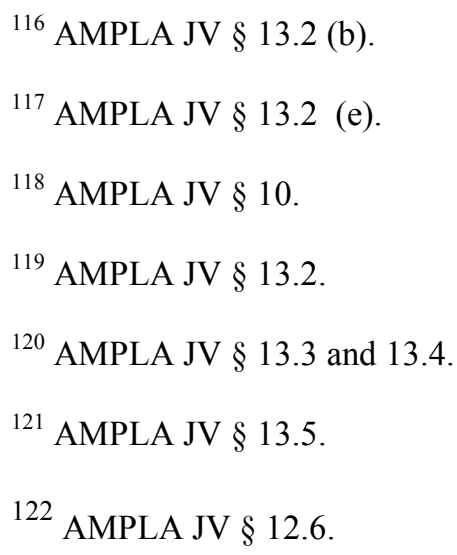


the outstanding expenditure until the default is cured by the defaulting party. Fifth, the form provides the non-defaulting party with the possibility of enforcing a buy-out or a cross charge resolution.

The Australian model does provide a fair and balanced provision because it can be used in relation to the default of any member of the JV rather than being focused on the nonoperators. It also secures a buy-out procedure which avoids the possibility of being defined as a penalty and therefore of being unenforceable; but it does refer to a compensation provision which could be considered a penalty depending on how it is structured. Nevertheless, the form also allows the non-defaulting party to refuse the expert determination and to use the cross charge disposition. Furthermore, the form also avoids the need to obtain consent from the defaulting party as a power of attorney is clearly provided for.

The Australian JV, therefore, seems considerably more favourable to the defaulting party than an average JOA, even though it gives some measure of choice to the non-defaulting parties about how the default will be resolved - by buy-out or by cross charge. Assuming that the non-operator is likely to face more financial problems than the operator, this JV model form provides more comfort to a party with fewer financial resources. It does not, however, adequately address the decommissioning issues or exploration risks.

\section{AIPN JOA Model ${ }^{123}$ (the International model)}

The AIPN JOA Model form provides a wider definition of default than usual by including in it not only failure to contribute to an applicable cash call, but also failure to obtain or maintain insurance related to the joint operations. ${ }^{124}$ Nevertheless, both alternatives are directly related to the financial resources of the joint operations.

The content of the default notice is highly regulated, mainly in order to clarify the precise reason why a party is receiving the notice. Another positive feature is that it is drafted in a

\footnotetext{
123 The AIPN recently published the newest JOA version (early March 2012). Such version updated and clarified the general wording for this provision. However, the most relevant difference is the implementation of a withering option. Nevertheless, these changes will not affect the main point of this paper as an unsuccessful exploration are not secured between the JOA parties but the decommissioning issue was already addressed by the previous version. For this reason, it will be analysed the old and familiar 2002 JOA Model form.
}

${ }^{124}$ AIPN JOA $\S 8.1($ A). 
way that could apply to any party of the JOA rather than exclusively to the non-operators. ${ }^{125}$ It provides a special paragraph addressing the particularities of an operator's breach. If that occurs, all payments related to the joint operations must be made to the non-defaulting party who issued the default notice to the operator. The non-defaulting parties also have power to request a cash call if necessary. ${ }^{126}$

The defaulting period commences 5 days after the relevant notice has been issued and ends when the default has been remedied in full. ${ }^{127}$ If the defaulting party does not cure this breach within 5 days, then it is regarded as being in default. However, the non-defaulting parties must cover the breach otherwise they too will be in default. ${ }^{128}$ This approach is exceptionally harsh since the breach has been caused by another party, but its purpose is to safeguard the standing of the petroleum title.

The consequences of default are quite severe as the defaulting party loses almost all of its rights (to vote in the Opcom, to transfer its interest, to withdraw from the agreement, to receive information, and to lift its production share, among others). ${ }^{129}$ If any proposal of work is submitted during the default period, then the defaulting party is automatically 'excluded' from it.

During the default period the non-defaulting parties can use the defaulting entitlement to cover the applicable expenditures and costs. They can also create a reserve fund to cover future expenditure related to abandonment and cessation of operations, which works as follows:

(A) During the Default Period, the Defaulting Party shall not have a right to its Entitlement, which shall vest in and be the property of the non-defaulting Parties. Operator (or the notifying Party if Operator is a Defaulting Party) shall be authorized to sell such Entitlement in an arm's-length sale on terms

\footnotetext{
${ }^{125}$ AIPN JOA $\S 8.3$.

${ }^{126}$ AIPN JOA $\S 8.3(\mathrm{C})$.

${ }^{127}$ AIPN JOA $\S 8.1(\mathrm{~B})$.

${ }^{128}$ AIPN JOA $\S 8.3(B)$.

${ }^{129}$ AIPN JOA $§ 8.2$.
} 
that are commercially reasonable under the circumstances and, after deducting all costs, charges and expenses incurred in connection with such sale, pay the net proceeds to the non-defaulting Parties in proportion to the amounts they are owed by the Defaulting Party as a part of the Total Amount in Default (in payment of first the interest and then the principal) and apply such net proceeds toward the establishment of the Reserve Fund (as defined in Article 8.4(C)), if applicable, until all such Total Amount in Default is recovered and such Reserve Fund is established. Any surplus remaining shall be paid to the Defaulting Party, and any deficiency shall remain a debt due from the Defaulting Party to the non-defaulting Parties. When making sales under this Article 8.4(A), the non-defaulting Parties shall have no obligation to share any existing market or obtain a price equal to the price at which their own production is sold.

(B) If Operator disposes of any Joint Property or if any other credit or adjustment is made to the Joint Account during the Default Period, Operator (or the notifying Party if Operator is a Defaulting Party) shall be entitled to apply the Defaulting Party's Participating Interest share of the proceeds of such disposal, credit or adjustment against the Total Amount in Default (against first the interest and then the principal) and toward the establishment of the Reserve Fund (as defined in Article 8.4(C)), if applicable. Any surplus remaining shall be paid to the Defaulting Party, and any deficiency shall remain a debt due from the Defaulting Party to the non-defaulting Parties.

(C) The non-defaulting Parties shall be entitled to apply the net proceeds received under Articles 8.4(A) and 8.4(B) toward the creation of a reserve fund (the "Reserve Fund") in an amount equal to the Defaulting Party's Participating Interest share of: (i) the estimated cost to abandon any wells and other property in which the Defaulting Party participated; (ii) the estimated cost of severance benefits for local employees upon cessation of operations; and (iii) any other identifiable costs that the non-defaulting Parties anticipate will be incurred in connection with the cessation of operations. Upon the conclusion of the Default Period, all amounts held in the Reserve Fund shall be returned to the Party previously in Default. ${ }^{130}$

This reserve fund is a reasonable approach to secure decommissioning liabilities, but it is only effective if the assets are worth enough to cover the costs. An optional provision available in the AIPN model known as 'Abandonment Security' might be more effective if properly implemented as described below:

If under the Contract or the Laws /Regulations, the Parties are or become obliged to pay or contribute to the cost of ceasing operations, then during preparation of a Development Plan, the Parties shall negotiate a security agreement, which shall be completed and executed by all Parties participating in such Development Plan prior to application for an Exploitation Area. The security agreement shall incorporate the following principles:

${ }^{130}$ AIPN JOA § 8.4. 
(A) a Security shall be provided by each such Party for each Calendar Year commencing with the Calendar Year in which the Discounted Net Value equals percent $\%$ ) of the Discounted Net Cost; and

(B) the amount of the Security required to be provided by each such Party in any Calendar Year (including any security previously provided which will still be current throughout such Calendar Year) shall be equal to the amount by which percent $\%)$ of the Discounted Net Cost exceeds the Discounted Net Value.

"Discounted Net Cost" means that portion of each Party's anticipated before tax cost of ceasing operations in accordance with the Laws /Regulations which remains after deduction of salvage value. Such portion should be calculated at the anticipated time of ceasing operations and discounted at the Discount Rate to December 31 of the Calendar Year in question.

"Discounted Net Value" means the value of each Party's estimated Entitlement which remains after payment of estimated liabilities and expenses required to win, save and transport such production to the delivery point and after deduction of estimated applicable taxes, royalties, imposts and levies on such production. Such Entitlement shall be calculated using estimated market prices and including taxes on income, discounted at the Discount Rate to December 31 of the Calendar Year in question. No account shall be taken of tax allowances expected to be available in respect of the costs of ceasing operations.

"Discount Rate" means the rate per annum equal to the one (1) month term, London Interbank Offered Rate (LIBOR rate) for U.S. dollar deposits applicable to the date falling thirty (30) Business Days prior to the start of a Calendar Year as published in London by the Financial Times or if not published then by The Wall Street Journal. ${ }^{131}$

In addition to the right to lift the defaulting party's production share the AIPN JOA model provides three alternatives for the parties: forfeiture, buy-out and security interest (encumbrance). ${ }^{132}$ If the defaulting party does not cure the breach within 30 days, then one or more of these alternatives might be applicable. The forfeiture alternative is the hardest because the defaulting party loses everything. However, it is only applicable if the default persists for more than 30 days. Consequently, a party could go into default but remedy it within 30 days without major consequence. In order to avoid such behavior, the AIPN model provides for an option to prevent repetitive defaults, more precisely to discourage a party from using the non-defaulting parties as a source of short term loans. The JOA parties can decide in their agreement whether any single party can exercise this option or if a majority of

\footnotetext{
${ }^{131}$ AIPN JOA $\S 10.3$.

${ }^{132}$ AIPN JOA $\S 8.4$.
} 
the parties is needed to activate this forfeiture provision. Additionally, the parties may also implement restrictions over each participating interest in order to secure the payment of the cash calls. This alternative, however, might need further attention from the JOA parties concerning the registration and validity of such a mechanism .

Power of attorney is not explicitly delegated to the non-defaulting parties, but there is an obligation on all of them transfer their participation interest. The rights given to the nondefaulting parties do not limit each other and do not restrict any other right provided by law. In this case, however, the law is more likely to be explored by the defaulting parties than by the non-defaulting parties. In addition, the ongoing liabilities related to surrender and decommissioning persist regardless of the outcome of the default provision. ${ }^{133}$

The buy-out option in the international model is much more balanced than any alternative (especially in relation to a middle stage of a project). ${ }^{134}$ In fact, the buy-out mechanism is the only alternative which provides for an expert determination mechanism to resolve the default (if the parties cannot reach a consensus about the 'fair market value' minus the total amount of default). Besides, the buy-out option allows payment to be made in 4 installments starting from 15 days and finishing 545 days after the transfer date. ${ }^{135}$ In any case, the JOA parties have the flexibility to decide which of the alternatives they will implement during their negotiation. In addition, there is an explicit provision that the outcome of the default, whichever way it is resolved, should be reasonable and appropriate. This expresses a clear intention to avoid the clause being considered to be a penalty. ${ }^{136}$

\section{Greenlandic JOA Model}

The Greenlandic JOA model adopts a fairly detailed procedure regarding the establishment of a default. ${ }^{137}$ In this case, however, a NOC is also a member of the JOA so it is not surprising that the procedure does not apply to all parties involved but only to the private ones.

\footnotetext{
${ }^{133}$ AIPN JOA $\S 8.4$ and 8.5 .

${ }^{134}$ Ibid.

${ }^{135}$ AIPN JOA $§ 8.4$.

${ }^{136}$ AIPN JOA $\S 8.5$.

${ }^{137}$ Greenlandic JOA $§ 11.1$.
} 
First, the operator must notify the defaulting party as soon as possible about such default, ${ }^{138}$ although the situation where the operator is the defaulting party is not mentioned. Second, all the non-defaulting parties have to cover the breach of the defaulting party in order to safeguard the execution of on-going activities. ${ }^{139}$ The operator has to issue another notice for the non-defaulting parties regarding their additional obligation which must be fulfilled within 6 days or they too will be in default. ${ }^{140}$ There are two interesting provisions regarding such additional funds: one increases the task of the operator to find additional resources that might be necessary to cover the breach, though again it does not address the situation where the operator is the defaulting party. Another provision excludes the NOC (representing the government in the consortium) from the obligation to cover any part of the required expenditures. This is a measure designed to preserve the national interest. The NOC is not subject to the default provision until a defined point since other companies are obliged to provide all of the missing funds.

The defaulting party can cure its breach at any time. ${ }^{141}$ But, if it fails to do so within 6 days, there are several consequences. First, the defaulting party loses its right of ownership of its share of production and as a consequence the non-defaulting parties acquire the defaulting party's share and can use it to cover the applicable costs. ${ }^{142}$ Second, the defaulting party loses its right to participate in the Opcom while any decision taken by the Opcom is binding on the defaulting party. In addition, the defaulting party also loses the basic right of access to information. ${ }^{143}$ Third, if the defaulting party does not cure its breach within 60 days from the relevant notice, then the non-defaulting parties can remove its participating interest. ${ }^{144}$ No

\footnotetext{
${ }^{138}$ Greenlandic JOA $\S 11.1$ (a).

${ }^{139}$ Greenlandic JOA § 11.1 (b).

${ }^{140}$ Greenlandic JOA $§ 11.1$ (c) (d).

${ }^{141}$ Greenlandic JOA $§ 11.2$.

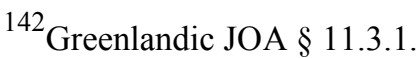

${ }^{143}$ Greenlandic JOA $§ ~ 11.3 .2$.

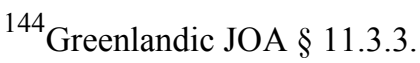


abandonment is allowed, however, prior to the completion of the minimum work obligations (MWO). In addition, this model adopts a similar approach to the British one in seeking to address decommissioning liabilities. It is explained in section 3.18.3 (Abandonment Agreement):

The Parties participating in a development will before submission of a development plan to the BMP agree the terms of an Abandonment Agreement. Such agreement shall state the terms for the security, which each Party shall provide to the other Parties for its share of the costs of abandonment (which expression shall include demolition and removal together with any necessary site reinstatement) of all or part of any facilities, equipment, installations and pipelines used in connection with the Joint Operations ("Abandonment"). The Abandonment Agreement shall state the date from which the security shall be provided, based on estimates of:

(i) The likely costs of Abandonment; and

(ii) The net funds (to be defined in the Abandonment Agreement, but in any case to be net of expenses of production and costs of Abandonment) to be made available from production of Hydrocarbons from a Discovery to discharge the costs of Abandonment. The Abandonment Agreement shall further state that, if a Party fails to provide and maintain the agreed security, such failure shall also constitute a default under this Agreement and the provisions of Article 11.3 shall apply to such default. The Abandonment Agreement shall further provide for the provision of security in case of assignment. ${ }^{145}$

There is an explicit statement that the default will only be valid if government approval is obtained and that default will not release the defaulting party from its part of the decommissioning obligations. ${ }^{146}$ In this sense, the Greenlandic model protects the national interest by making sure that the government (that is, the taxpayer) will not end up paying for the removal of the installation or infrastructure since it wishes to maintain as many parties as possible for the decommissioning obligations.

The approach of the Greenlandic JOA model is unique because it includes further protections for the NOC and also imposes strict obligations on the non-defaulting parties. Although it adopts several standard procedures (in relation to the notice, to the time to cure the breach and consequences of the default) it does not even contemplate a default caused by the operator nor by exploratory risks. Nevertheless, the model gives a special weight to decommissioning.

\footnotetext{
${ }^{145}$ Greenlandic JOA § 3.18 .3 .

${ }^{146}$ Greenlandic JOA § 11.3 .4
} 


\subsection{Actual agreements observed}

The model forms described in the previous section are based on attempts, largely by industry associations, but with a good deal of participations in places by governments, to reduce the problem of default in petroleum industry joint ventures. None of the models is a rigid set of unalterable rules. JOAs are free to adopt any measures that they wish, but in practice nearly all of them choose one of the standard regional forms - in other words, a set of procedures which include some variant of the forfeiture solution to the problem of default by one of the JOA parties.

The model forms tend to prescribe the accepted practice in a particular region. This approach reduces the length of negotiations as most of the terms should be reasonably acceptable for the parties. This point has been confirmed by a close examination of the nature of more than 60 agreements which have actually been signed and in operation at some time during the period from 1967 to the present, most of them since 1990. The countries and regions in which these agreements operated include the UKCS, Egypt, Nigeria, Netherlands, Ghana, Madagascar, Angola, Brazil and Mauritania.

Almost all of these JOAs adopted one of the standard models of agreement outlined in the previous section, using either a forfeiture or a buy-out mechanism and in a very limited number of cases, mortgage or lien mechanisms, which are in effect variants of forfeiture. The only exception to this rule refers to JOAs signed before 1970's as they did not provide for any default mechanism.

The vast majority of these agreements completely or partially ignored the decommissioning issues since this was not a historical concern. But all of them ignored the exploratory risk. The consequence of this is that default mechanisms are currently very likely to be ineffective because they rely on the value of the petroleum title to guarantee the required payments.

\subsection{The limits of standard practice}

The basic function of the agreements which have been discussed is how the risks and costs of a joint operation are shared between the various parties involved in its execution. Consequently, the financial contributions of the parties which cover the expenditure of the 
consortium is crucial to maintaining the good standing of the consortium's petroleum title which cannot be done without the necessary financial means. So the question of default how to avoid it, or to deal with it if it cannot be avoided - involves an area of serious risk for a consortium and all its components; the failure of one party will increases the amount which the other parties will have to pay to maintain the performance of the joint operations. ${ }^{147}$

In a mature province default is a very serious danger for future operations because insufficient financial strength can easily threaten the full maintenance of joint activities over a long time scale. This fact is easy to understand since mature provinces are unlikely to be dominated by major companies which have or can easily arrange financial resources to cover their expenditure. More frequently the companies in a mature province are smaller or medium size players who are likely to have considerably more difficulties in raising the required funds and so are likely to be willing to trade part of their share in the JV in order to raise those funds. In spite of this, the majority of JOAs (with three exceptions to be mentioned below) say little or nothing about decommissioning.

To solve the risk problems associated with the exploratory and decommissioning stages, the majority of the JOAs rely on the arrangements which exist between the licensees and the government. If the host government requires financial guarantees to carry out the minimal work program and discharge decommissioning liabilities then, in the event of default, the non-defaulting parties have some protection because, when all else fails, they could use these arrangements with governments to limit their liabilities. On the other hand, if the nondefaulting parties have to wait for the host government to execute these collaterals, then it is quite possible that the petroleum licence will be terminated and thus their whole project will be jeopardised.

The absence of arrangements to deal with default during the earlier and later stages of joint projects means that not a single JOA analysed in this paper provides a default mechanism which is safe enough to guarantee the sufficient cash to finance the consortium's activities from the beginning to the end of a project. Some JOA models, however, do provide a number of provisions which could help to solve this problem. For example the Canadian model

\footnotetext{
${ }^{147}$ Bernard Taverne (n.18) 141.
} 
provides a right for the operator to request proof from the non-operators about their capability to meet cash calls. This is a positive way to verify potential defaults in advance, but it does not guarantee that funds will be provided and it only applies to non-operators.

If the operator is the defaulting party the non-operators might not find out about its financial problems until it is already too late. ${ }^{148} \mathrm{~A}$ way to mitigate this risk would be to impose an obligation on the operator to confirm periodically to the remaining parties its ability to comply with its funding obligations. ${ }^{149}$

Another possible solution to the default problem is the use of a reserve fund, as mentioned in the AIPN (International) model. The use of reserve funds is quite common in Production Sharing regimes. But a reserve fund can be effective only if the value of the assets which it contains is sufficient to secure costs in a similar way to Decommissioning Security Agreements. But, even if reserve funds can make a contribution to avoiding the risks associated with decommissioning, they are unlikely to contribute to the other major problem, which is unsuccessful exploration, because reserves cannot be built up before a project provides any revenue.

Successful default provisions also require the qualities of balance and fairness. The idea that the same costs and responsibilities apply to all the parties involved (i.e. operator and nonoperators) is a key element for the present and even more in the future. In other words, balanced terms tend to avoid conflicts and disputes between the parties in a long term investment.

Therefore, effective default provision is important to protect the interests of the joint venture as a whole. As Roberts states, 'The business of exploring for and producing petroleum cannot simply stop because a party has decided not to pay for its share of the costs of those activities, and ultimately a default might even jeopardise the concession. ${ }^{150}$ On the other hand, the parties should not adopt unreasonable and possibly unenforceable provisions to deal with a

\footnotetext{
${ }^{148}$ Peter Roberts (n.18) 189.

${ }^{149}$ Ibid.

${ }^{150}$ Ibid 187.
} 
question which is such a sensitive one for the consortium. The principal goal of the default provision, therefore, is protection against the lack of financial resources to cover the joint expenditures. In addition, the JOA should be drafted carefully so as to avoid harmful forms of conduct, such as the use of the default mechanism as a means of obtaining short loans from the non-defaulting parties.

The research question posed in the introduction - how can companies protect themselves against the problems created by the default of another participant in a long term petroleum joint venture - is not fully answered by any of the JOAs discussed in this paper because none of them provide clear security in the case of unsuccessful exploration and decommissioning liabilities. $^{151}$

The JOAs for the most part ignore the two riskiest stages of a venture: the first is when companies spend a lot of money but find no petroleum (the unsuccessful exploration risk), and the second is the risk at the end of production when the companies need to pay huge amounts of money for decommissioning but have no petroleum or other saleable assets from the venture in order to offset the costs (the decommissioning risk). Productive ventures often choose to let other arrangements deal with these risks, usually the petroleum title between the host government and the licensees. In three cases, however, the British, International and Greenlandic JOA models do make a clear reference to a Decommissioning Security Agreement which could guarantee the fulfillment of decommissioning liabilities which are part of the JOA, even though these three JOAs still do not address the unsuccessful exploration risks.

Joint ventures themselves perform an important role in guaranteeing the necessary continuation of cash-flow. The existence of more than one company in a venture is itself a way of spreading risks. This argument, however, is only as strong as the number of parties in the venture. The more parties in a consortium, the more non-defaulting parties are available to replace a part of the lost contributions due to the default. This, argument, however, is not a powerful one if there is only a single non-defaulting party which is obliged to assume all the

${ }^{151}$ Randall Wood, Oil and Gas, A.A.P.L. Form 610 Model Form Operating Agreement, Imposing Limitations on the Operator's Ability to Require Contribution from Nondefaulting Nonoperators (1983) 36 Okla. L. Rev. 733. 
funding demands once shared between two companies. And, even in a consortium of more parties, some may be so small that they cannot assume a sudden increase in the financial burdens placed on them by a default. ${ }^{152}$

The JOA standard model forms used in the petroleum industry contain a large number of rules designed to combat the bad effects of default. But they do not provide a strong enough guarantee that the cash contributions needed from the beginning of activities until the very last day of a successful petroleum operation will materialise.

Present and future operations, therefore, require more balanced and stronger terms to enhance the enforceability and efficacy of the JOA provisions. In Section 2.2 we saw that, within the broadly similar models of default provision in current use, a number of more unusual and relatively novel measures had been introduced. The next section of the paper will examine both these and other measures to see whether they could form the basis of a more effective default regime.

${ }^{152}$ Ibid 733-735. 


\section{Some available alternatives}

\subsection{Upfront Cash}

One alternative to the default mechanisms discussed in the previous Section is theoretically simple; the parties to the JV could be responsible for providing enough accessible upfront cash to meet all of the required expenditures.

In theory, it is possible to argue that the JV parties have agreed the minimal work program with the relevant host government. In this case, it is therefore possible in theory to determine the exploration costs in a single and upfront cash call. ${ }^{153}$ Nevertheless, exploration costs might be extremely high and might last as long as several years. And the data available before the award of the petroleum title will certainly change during the exploration phase, possibly requiring additional funds. This is more a theoretical than practical, however, because its implementation might be extremely challenging and difficult in the real world.

Although simple in theory, this kind of solution could, from an operational and financial perspective, be quite complicated since the money involved needs to be optimally managed and invested throughout the exploration period.

Moreover, in a mature province, where smaller, independent companies tend to be the main players it is unrealistic to imagine them having the resources to meet an upfront cash call. Providing upfront cash might seriously complicate life for these players since they often need all of their limited available financial resources.

It might be even more difficult to deal with decommissioning costs by means of upfront cash. In this phase of a joint project it is often very difficult to predict the timing of cash calls and often impossible to determine the final costs involved until the production and decommissioning are themselves concluded. Generally speaking, the host government requires annual updates on projected decommissioning costs after a certain point in the

\footnotetext{
153 Peter Roberts (n.18) 186.
} 
project (for instance, after the exploitation of half of the recoverable reserves). So it is very difficult to foresee the precise moment when calls for upfront cash will be made. ${ }^{154}$

\subsection{Collateral}

The petroleum industry is accustomed to providing collateral for host governments in order to guarantee the payment of both the minimal work program and sometimes for the decommissioning obligations. ${ }^{155}$

This kind of collateral is something which has arisen in practice rather than in response to some academic concept. The great majority of oil and gas countries require collaterals to guarantee the execution of the minimal work obligations. ${ }^{156}$ But the real problem is not in the vertical relationship between the host government and private firm, but rather the provision of effective collateral in the horizontal relationship (that is, between the private parties involved in the joint venture). This is because petroleum laws do not insist on this kind of guarantee whereas independent parties themselves try to obtain collateral from other private parties by employing their bargaining power with each other.

A number of different options can be settled by JV parties through bargaining power among themselves, as opposed to agreements made exclusively with the host government. But several hurdles complicate the enforceability of the guarantees and tricky questions exist concerning the distinction between a guarantee and an indemnity under the applicable law. These, however, are outside the scope of this paper. ${ }^{157}$

\footnotetext{
${ }^{154}$ Charez Golvala (n.11) 50.

155 Ibid.

${ }^{156}$ See: http://www.inp.gov.mz/Legal-Framework/EPCC-Model.

157 Penelope Warne, Judith Aidersey-Williams, Oil and Gas Contracts in the UKCS, How to Survive Them (2001) 19 Journal of Energy \& Natural Resources Law 314.
} 


\subsection{Parent Company Guarantee}

The oil and gas industries are highly globalised but most IOCs are still based in a specific country even though they operate on a world scale. As a result it is common to find large international holding companies establishing local companies in the particular country where they are exploring and where they produce oil and gas.

Frequently, these subsidiary companies might not have sufficient financial resources to guarantee their commitments since they are able to commit only their own capital and not that of the parent companies or their shareholders. Consequently, it is fairly common for the parent company to receive requests for guarantees related to the activities of their subsidiary companies. $^{158}$

Guarantees by parent companies might, in principle, be a solution to the problem of insufficient financial backup for the ongoing liabilities of a JV's operations. Obviously, however, the parent company can only contribute if it itself has enough funds to cover the liabilities. Even when it does have the funds it might take so long for a subsidiary to recover costs or credits from the parent companies that no cash is immediately available to the nondefaulting parties, but rather another source of funds to secure future claims for losses and damages if the subsidiary itself cannot afford to pay.

\subsection{Bank Guarantees, Letters of Credit and Insurance-Guarantees}

Bank guarantees, letters of credit, and insurance guarantees are all financial securities provided by a bank. ${ }^{159}$ As previously mentioned, the use of these securities is widespread in relations between the host governments and the licensees.

${ }^{158}$ Claude Duval (n.36) 299.

${ }^{159}$ There are other financial arrangements available in the capital market but it will not be explored in this paper as they follow the same concept of these above. For further information see: Thierry M Lauriol, Legal Aspects of Creating Security Interests over Mining Titles in the States Parties to the OHBLA (2001) Journal of Energy and National Resources Law Vol 19 No 3 2001, James E H Baily, Equitable Liens and Engineering, Procurement and Construction Contracts in the Oil and Gas Industry (2007) Journal of Energy and Natural Resources Law Vol 25 No 4, John D. Weidman, Oil and Gas, Operator's Liens in Bankruptcy, The Model Form Operating Agreement Versus the Trustee in Bankruptcy's Avoiding Powers (1984) 37 Okla. L. Rev. 141, John Cross, A Treatise on the Law of Lien and in Transitu (J.S. Littell, Philadelphia 1841). 
Unlike guarantees and credits from a parent company, these arrangements with banks provide immediate access to cash which makes them far more attractive for the non-defaulting parties. But, since initially it is not always possible to determine which will be the defaulting parties, this solution really requires all parties to issue reciprocal securities.

The problems of using this solution have become clear in the case of the UKCS. The British government has possessed the power to demand a financial contribution from any party with an interest (even a historic one) in any petroleum licence, in order to guarantee that decommissioning liabilities will not have to be performed by the government. Any licensee assigning its participating interest to another party is likely to be required to present guarantees of its liability to fulfill decommissioning liabilities in the future. In other words, an assignor will request a bank guarantee, letter of credit or insurance-guarantee from its potential buyer to secure any ongoing liability related to decommissioning. A negative consequence of this has been to deter mergers and acquisitions since not all companies are capable of providing this security; this is a problem which is more severe in mature provinces.

A bank guarantee, letter of credit or insurance-guarantee could, again in principle, secure the financial requirements of a particular consortium. But, again, this might not be very practical (especially in a mature province). In addition, during negotiations the parties are very unlikely to get a combination of collateral instruments even though that would be an ideal scenario for the non-defaulting party. For example, a company might not be willing to provide both a parent company guarantee and a bank guarantee. The company which is giving the collaterals might argue that one collateral is enough: more could create unnecessary burdens. But the other company might argue that the parent company guarantee is only a future security rather than an immediate one like a letter of credit. In other words, it is not a simple task to obtain several types of collaterals even though it would be the best solution to mitigate the risk of default.

\subsection{Encumbrance/Secured Interest}

The JOA parties can use their participating interest in the consortium (including related rights such as their share of property and production) to guarantee the fulfilment of the financial 
commitments. Several mechanisms available to the parties to do this. As described before, the most common mechanisms in the petroleum industry are the mortgage (charges) and liens. This paper does not pretend to analyse all the available alternatives to secure any participant interest or to determine the distinction between them. The most relevant point, however, is the common concept that all of them impose restrictions on each individual party's rights related to the participating interest (including related rights) so that it can be used to guarantee future payments.

The establishment of liens or mortgages might ensure the payment of ongoing costs. ${ }^{160} \mathrm{~A}$ lien or a mortgage could be created over each party's share of production, participating interest or any other property. As previously mentioned, this solution is quite common in North American JOA models. ${ }^{161}$

For exploration activities, however, this solution is very unlikely to be useful. First, as the name suggests, there is no production during this stage. Second, most of the installations and equipment are put into place after the design of a development plan for a discovery. It is difficult, therefore, to imagine equipment or installations which are valuable enough to provide security for a lien, except in the case of drilling rigs or platforms, as long as they are acquired in the name of the consortium or one of the members of the joint venture rather than rented from a third party.

In the case of decommissioning, a lien or charge over the defaulter's share of the joint property or production might not be a reliable protection at such a late stage in the life of the field. ${ }^{162}$ This is for quite simple reasons: first, production has nearly if not completely finished; and, second, most of the relevant properties are more likely to be liabilities than assets since they have to be decommissioned; and, in addition, depending on the applicable

\footnotetext{
${ }^{160}$ For further information about insurance and liens see: D. O. Sabey and others, 'Indemnity and Insurance Clauses in Joint Venture, Farmout and Joint Operating Agreements' (1970) 8 Alberta Law Review 210, John D. Weidman, 'Oil and Gas, Operator's Liens in Bankruptcy, The Model Form Operating Agreement Versus the Trustee in bankruptcy's Avoiding Powers' (1984) 37 Oklahoma Law Review 141, David Dezhi Peng, Insurance and Legal Issues in the Oil Industry (Graham \&Trotman, London 1993), Andrew B. Derman, Protecting Oil and Gas Lien and Security Interests, Use of Memorandum of Operating Agreement and Financing Statement (1987). Availabe at http://www.tklaw.com/resources/documents/Protecting\%20Oil\&\%20Gas\%20Lien\%20\%20Derman.pdf.

${ }^{161}$ Kenneth Charles Mildwaters (n.23) 268.

${ }^{162}$ Hew Dundas (n.32) 12-15.
} 
law, this solution might also require to be formally registered to become enforceable, something which would increase the cost. ${ }^{163}$ But if the lien is not registered as duly required by law it might be void or at least unenforceable against third parties.

In theory, this solution could be attractive for JOA parties because it avoids uncertainties about the enforceability of the default provision and protects the non-defaulting parties from creditors in a potential insolvency case. On the other hand, there are three clear drawbacks to this solution: mortgages or liens might require public registration to be enforceable; the burden on each participant interest may be unnecessary; and the costs of implementation may be high. ${ }^{164}$

These drawbacks suggest, therefore, that liens or mortgages are unlikely to provide higher security unless the parties have substantial properties available or the production of the field is still not close to the end of its life. Even then, the formalities involved in the use of liens are not at present well accepted. ${ }^{165}$ This is why the lien or mortgage mechanisms do not solve the central problem raised in this paper, although it could improve other aspects of enforceability of the forfeiture mechanism because it is not a penal provision and because it grants priority over future creditors. Thus, an encumbrance mechanism could only be useful if the JOA parties provide security over other assets than those related to their JOA.

\subsection{Cross-Default}

A more complex solution for the security of the joint enterprise might be found outside the scope of either the petroleum title or the relevant JOA. This is the cross-default mechanism under which each JOA party must own other oil and gas assets which provide a guarantee of its financial commitments in the consortium. This default mechanism would involve several (or at least more than one) petroleum title so a default in one title would trigger the default on another title. This type of cross default is not yet widely known in the petroleum industry since it involves several obstacles outside the control of the parties, such as third parties'

\footnotetext{
${ }^{163}$ Michael Taylor (n.18) 77.

${ }^{164}$ Peter Roberts (n.18) 191-192.

${ }^{165}$ See section 3.5.
} 
rights (for example, preemptive rights and right of first refusal) and governmental approval. ${ }^{166}$ In other words, the parties involved in the other licence, or indeed the government, might not allow the implementation of such a provision because it would allow the access of an outside party to their petroleum title.

A similar procedure, however, far more familiar in the petroleum industry, is that of crossdefault within the same petroleum title. For example if a party develops a sole risk project it will ultimately segregate the petroleum title with different ownership (at least between the JOA members). For example, party A, B, C and D have equal shares in a petroleum title. But if $\mathrm{A}$ and $\mathrm{B}$ develop a sole risk project in a piece of the licensed area, then this title would have a section divided equally among all parties and another with completely different ownership. In this latter case, a default in A and B's sole risk project could affect the other parties. In most cases the government will not consider this segregation of title but will regard the area as one. For this reason, segregation tends to be an internal arrangement between the parties. Thus both the non-defaulting party and the other parties would favour the implementation of cross default in order to protect the petroleum title as a whole.

Theoretically, from a business perspective, this solution sounds very attractive, but it is a very complicated solution from a practical perspective. First, it is important to understand if the relevant jurisdiction requires governmental approval to change for the assignment of interest. For example a cross default would be easier to implement in North America than elsewhere since an assignment of the title is free from governmental control, but it would be more difficult to implement in the North Sea where the assignment of title is heavily controlled by the UK and Norway. Second, if the nature of the petroleum title involved is a PSA or a service contract, or if the party concerned is an operator rather than a non-operator, the problems of implementing this mechanism might be even greater. Third, the other consortium parties might not authorize the implementation of a cross-default because they might have rights (a preferential right or a right of first refusal) which could prevent the assignment of the defaulting party's interest to a third party (from outside this JOA).

Therefore, a cross-default may sound like a good commercial solution, but to be completely effective it would have to be forbiddingly complicated.

166 Peter Roberts (n.18) 186. 


\subsection{Premium}

Another potential solution is a premium mechanism which consists of an obligation upon the defaulting party to pay a fee to the non-defaulters to compensate for the default. ${ }^{167}$ Although this mechanism should deter a potential default, it will not solve the original difficulty, raised throughout this paper: how can a premium be paid if there is no production or if the 'asset' is in fact a liability?

Additionally, a premium mechanism would face uncertainties similar to those relating to the forfeiture mechanism. These would make it difficult to determine the value of the premium in relation to the amount of the default.

\subsection{Set-Off}

The right of set-off is another possible way to solve a default concern. ${ }^{168}$ In this case, a nondefaulting party would have the right to offset any other payment he was supposed to make to the defaulting party.

In theory, a set-off solution might be effective. But in practice it only works if this right includes any payment (inside and outside) the petroleum title otherwise it will experience the same problems as the other mechanisms (because the petroleum title must be an asset with positive value).

\subsection{General Law}

The applicable law might provide further remedies for the non-defaulting party.

Bartlett states that "the oil and gas industry is not a law unto itself and must operate within the strictures of the general principles of the law of contract and property.' 169

\footnotetext{
${ }^{167}$ Terence Daintith (n.18) 1146-1147.

${ }^{168}$ Richard H. Bartlett, Rights and Remedies of an Operator vis-à-vis a Defaulting Non-Operator under Joint and Unit Operating Agreements (1972) 10 Alta. L. Rev. 307.
} 
The defaulting party might be sued for the loss and damages it caused to the other parties. ${ }^{170}$ As a matter of fact, some contracts explicitly refer to the right to sue the defaulting party. Here is one example:

"Right to Sue Defaulter

(a) Suit

The Outstanding Amount is recoverable by suit of Operator.

(b) Outstanding Amount

The Outstanding Amount is the aggregate of:

(i) the Unpaid Called Sum;

(ii) all interest payable under this Agreement, and

(iii) all expenses and loss incurred by any other Party by reason of

the default, including all court costs and legal fees on a full

indemnity basis (including solicitor and own client costs)."

This solution, however, like some others, might take a dauntingly long time to be effective (even if there are sources of compensation available); and it will not solve the requirement to provide an emergency cash contribution. ${ }^{171}$

Another possible effective solution might be a provisional court order, in order to avoid the deterioration of the defaulting party's financial capability, for example to avoid payments being made to third-parties. This solution will not solve the problem of finding the immediate cash contribution required; but it could be a valuable protection against future claims for compensation. $^{172}$

So the reality seems to be that the remedies available in general law will not solve the main difficulties produced by the defaulting party for the non-defaulting parties. ${ }^{173}$

${ }^{169}$ Ibid 288.

\footnotetext{
170 'Thus, the amount in default will be due as a debt owing from the defaulting party to the non-defaulting parties (where the amount of that debt is determined as the amount of the default which has been made good by the non-defaulting parties), together with accrued interest. The non-defaulting parties could always elect to sue the defaulting party through the courts for recovery of that debt.' Peter Roberts (n.18) 188-189.

${ }^{171}$ Richard H. Bartlett (n.174) 294.

${ }^{172}$ Will H. Knull III and others, Accounting for Uncertainty in Discounted Cash Flow Valuation of Upstream Oil and Gas Investments (2007) 25 J. Energy Nat. Resources L. 275.

${ }^{173}$ Richard H. Bartlett (n.174) 293.
} 


\section{Other Concerns}

\subsection{Governmental Concerns}

The default mechanism might face several problems involving the Host Government. For instance, most jurisdictions will require governmental approval to change the parties in the petroleum title and in the JOA. Procedures established in the JOA therefore must conform to those of the petroleum title. If there is no coordination between these instruments, then awkward questions ${ }^{174}$ are liable to arise such as what happens when a party has defaulted and been removed from the JOA but remains in the licence?

Another difficulty in implementing a default provision occurs in a JOA of which a NOC is a member. The Greenlandic model (along with many other agreements) explicitly excludes the NOC from the application of the forfeiture provision. But, whether or not a defaulting NOC within a JOA is sanctioned, it is likely to be a complex process in which the treatment of different parties in the agreement is not balanced. ${ }^{175}$

Another concern related to NOCs and the implementation of the default mechanism is that the NOC might have the benefit of foreign sovereign immunity which might make obtaining a practical result out of the default mechanism more difficult. ${ }^{176}$ Consequently, if a NOC is part of a JV, then the application of the default mechanism might be even more complicated.

\subsection{Repetitive Breach}

A default should only be recognised once the defaulting party has failed to remedy the breach within a certain number of days. But a defaulting party might abuse this provision by being guilty of repeated defaults and remedying them before forfeiture takes place. In other words, one party might abuse the other parties, treating them as temporary lenders. For this reason,

\footnotetext{
${ }^{174}$ Ibid 195.

${ }^{175}$ Peter Roberts (n.18) 193.

${ }^{176}$ Ibid.
} 
some JOAs extend the definition of default to cover repetitive lateness in the making of payments. $^{177}$

The default mechanism, therefore, should include the necessary elements not only to secure the cash contributions from all parties throughout the entire project, but also to deter disloyal behaviour, delaying its cash contributions rather than paying them on time.

\subsection{Force Majeure}

A defaulting party might try to use any provision contained in the JOA to support its position. Hence, in order to protect the consortium, JOAs must have the same protection that Host Governments commonly provide for the payment of the government take, namely that a plea of force majeure cannot be applied to the financial obligations to the consortium of one its members. The JOA parties should make clear that force majeure cannot be used to justify a default. $^{178}$

\section{Conclusion}

The purpose of the default provision, as we have seen, was to create a threat to deter default as much or more than a mechanism to solve it after the event. A threat, however, can only be effective if what it threatens is sufficiently large. For example, the possibility or certainty of a party's losing its participation interest or rights over a large producing field could be a real threat. On the other hand, losing rights on a field at the end of its life might be no threat at all.

Oil and gas producing countries such as the UK and Norway are moving towards their maturity. Increasingly the smaller and independent players are engaging in oil and gas exploration of a very different kind to the traditional activities performed by the major

\footnotetext{
${ }^{177}$ Ibid 187.

${ }^{178}$ Ibid 186
} 
international companies. This change in pattern is widely expected to result in an increase of defaults in the petroleum industry. ${ }^{179}$

Although oil and gas companies are neither bankers nor lenders, some of them can be expected to exploit any loop-holes they can find in oil contracts to obtain cheaper finance at the expense of fellow members of joint ventures. ${ }^{180}$ So the JOA parties need to deter such behaviour.

The aim of the default provision is to provide certainty and stability for the financial contributions which will be required throughout the life of the JV. The parties to it, therefore, must be aware of all the implications of the default provision and potential alternatives to it. $^{181}$

The most popular solution to default is forfeiture (or some variant of it). This seems to interest JVs because it does not need to be officially registered as would a mortgage or a lien. But it also has pitfalls. Even if the courts recognise the enforceability of a total forfeiture provision, the non-defaulting parties may face a series of additional hurdles in enforcing it: for instance (in the absence of a power of attorney) the defaulting party may be unwilling to assign its interests; or the Government might not be willing to accept such assignment. But ultimately the non-defaulting parties will bear all the risks and liabilities related to the petroleum title because the defaulting party will have been removed from the consortium (unless otherwise provided in their agreement). ${ }^{182}$ The most problematic issue for the forfeiture solution, however, is that of the value of the forfeited asset itself. If it has a significant value, then forfeiture could stand as a real threat to the potential defaulter. On the other hand, if the 'asset' is no longer really an asset but has become a liability (for example, an unsuccessful exploration programme), then it could even encourage a default.

\footnotetext{
${ }^{179}$ Ibid 202.

180 Ibid 202.

${ }^{181}$ Ibid 226.

182 See: Hew Dundas (n.32) 10, Claude Duval (n.36) 299, Sandy Shaw (n.12) 25, Chris Thorpe (n.14) $138-140$ and Charez Golvala (n.11) 77-81.
} 
There are several alternative ways for oil and gas enterprises to improve their JVs and obtain the all-important cash contributions throughout the life of a project. ${ }^{183}$ The petroleum industry's approach to this problem, however, has focussed too much on legal formulas to enforce the default and too little on the efficacy of the mechanism. A good example of this situation is the withering provision (see Section 2.1) which aims to reduce the value of assets forfeited to match the amount of default (in other words a proportional rather than a total forfeiture). This might have some relevance to establishing the enforceability of the default provision but it will not assist the efficacy of the default mechanism during an unsuccessful exploration or after the end of production. ${ }^{184}$

The provision of adequate collateral also looks like a good solution but it suffers from certain impracticalities: smaller companies are unlikely to be able to provide large amounts of collateral; and some companies might have problems in raising more capital due to commitments to previous creditors. ${ }^{185}$ There could still be a positive solution along these lines if collateral were to play a role which changes according to the size or stage of a project. From Davis's description of this technique in the construction industry, one might draw the conclusion that it is also applicable to the petroleum industry: 'it is often necessary to combine different types of security device; and an awareness of how they interact and support each other is a useful skill for a construction lawyer to cultivate.' ${ }^{186}$

Many of the alternatives mentioned here have positive and negative features which vary in accordance with the particular phase of the project. For example, collateral might work reasonably well during an exploration phase while forfeiture might be more appropriate during the development phase. A cross default is possibly the alternative with greatest

\footnotetext{
${ }^{183}$ David F. Asmus, 'The 1995 Model Form International Operating Agreement' (1996) 14 J. Energy \& Nat. Resources L. 25.

${ }^{184}$ Ibid.

185 'Formal security is rare because the debtor has usually fully charged its assets and promised its secured creditors not to grant further security over the same property. Another potential pitfall is that the security may be voidable as a preference under s.239 of the Insolvency Act 1986. In the Australian case of G \& M Aldridge Pty Ltd v Walsh an employer transferred units in a property fund to trade contractors as security for sums due under final accounts. Realisations from the security were minimal, but even they were repayable as preferences. A second, or third charge may also be vulnerable to further dealings in the property by the employer, or prior charge holders.' Richard Davis, Remedial security and construction contracts (2011) 27 (6) Const. L.J. 480.

${ }^{186}$ Ibid.
} 
suitability in a variety of different stages; but it only works if the party has more than one high-value asset (in other words during a development or production phase). This suggests that the parties should construct their mutual agreements in a way which addresses the risks and particularities of each phase of a project. ${ }^{187}$

Not a single one of the JOAs examined in this research, however, provides enough financial security from the beginning to the end of a project. If the parties do not provide an adequate anti-default mechanism in their JOA, then no remedy will be available to solve the problem effectively. If no solution is available for non-defaulting parties, then the title to the petroleum might be jeopardized - precisely what the agreement is designed to avoid. ${ }^{188}$

The petroleum industry faces similar problems in this respect to the construction industry, because high risks are involved before the positive cash flow starts. It is very difficult to obtain project finance, especially to implement collaterals, during an early stage of the project. That is why it is so difficult to solve the concerns raised in this paper. Nonetheless, the complexity of the problem should not be a reason to ignore it since the consequences of neglect might be very harsh and painful. ${ }^{189}$

The contract, however, should not impose excessive burdens on the contracting parties, something which might jeopardise the existence of such an industry which deals with such great risks both below and above the ground. As emphasised in the opening paragraph of this paper, the petroleum industry deals with multiple simultaneous risks. Oil and gas players obviously have to pay attention to such physical risks but not at the cost of ignoring contractual risks. These, like most kinds of risk, are essentially questions of reducing the uncertainty through measurement and control. ${ }^{190}$

\footnotetext{
${ }^{187}$ Bill Manning (n.1) 343.

${ }^{188}$ Richard H. Bartlett (n.174) 312.

${ }^{189}$ See: Scott McConnel, Project Financing in the Energy Industry and its Impact on Completion Risk (2001) 20(2) Australian Mining and Petroleum Law Journal 148 and Robert C. Nicholls, A review of some aspects of the organization and financing of mineral resource ventures University of South Wales Law Journal Vol 1271.

${ }^{190}$ Ibid.
} 
Before firms combine their efforts in a joint venture they should give weight to the reputation and financial conditions of the oil and gas companies involved. The CAPL (Canadian) model provides a highly efficient way of doing this by allowing the operator to verify the financial capabilities of the non-operators. These financial statements still, however, have several flaws, for example, they cannot accurately portray the dynamic of the company, so they will be out of date as soon as they are printed. Complexity in the corporate chain, in which there might be a great number of intermediate companies between the target and the holding company, also makes the mutual assessment of the state of potential partners difficult. ${ }^{191}$

Reputational and credit analyses are important but seldom decisive matters. In a mature province, for example, smaller and independent companies with less financial strength are always going to be present. And, in any case, even major companies might suffer periods of financial strain as a result of exposure to the financial market. Any company might have the financial capability of paying but could for any number of reasons decide not to pay. In the face of a multitude of factors which might lead to default, the answer is to provide a default mechanism which is tailored to these factors, especially the particular needs of different stages of the project. Whatever it is designed to say, default provision needs to be drafted with extreme care in order to protect the non-defaulting parties' interest, and to provide an enforceable and reasonable resolution. ${ }^{192}$

\footnotetext{
191 Ashley Wright and others, AIPN AAP Event, Forewarned is Forearmed: Joint Ventures and Insolvency 26 February 2009.

192 'The foregoing discussion illustrates that great care must be taken when negotiating an international operating agreement to include remedial provisions which will be enforceable (not only legally, but also practically in terms of the existence of workable enforcement processes) under the law selected as the governing law of the agreement and under the law of the host country.' Michael D. Josephson, How far does the CAPL travel? A comparative overview of the CAPL Model Form Operating Procedure and the AIPN Model Form International Operating Agreement (2003-2004) 41 Alta. L. Rev. 22 2003-2004.
} 


\section{Glossary}

AFE: an authority for the operator to incur Joint Expenditure under an Approved Programme and Budget or otherwise in accordance with the JOA.

Cash call: any request for the parties to advance their respective Participating Interest shares of estimated cash requirements for the next Calendar Month's Joint Operations in accordance with an approved Work Program and Budget.

Commercial discovery: any discovery that is sufficient to entitle the Parties to apply for authorization from the government to commence exploitation.

Consenting party: a party who agrees to participate in and pay its share of the cost of an exclusive operation.

Decommissioning: all work required for the abandonment of Joint Property in accordance with good oil field practice and applicable legal obligations, including, where required, plugging of wells, abandonment, disposal, demolition, removal and/or cleanup of facilities, and any necessary site remediation and restoration.

Default Amount: the amount of the Defaulting Party's share of Joint Account charges that the Defaulting Party has failed to pay when due under the JOA.

Default Notice: the notice of default given to a Defaulting Party.

Defaulting Party means any Party that fails to:

(1) pay when due its share of Joint Account expenses (including cash advances and interest); or

(2) obtain and maintain any Security required of such Party under the Contract or JOA;

Default Period: the period beginning on the specified business day after the date that the Default Notice is received and ending when the Defaulting Party has remedied its default in full by paying the Total Amount in Default.

Development Plan: an overall plan and cost estimate for the development of Hydrocarbons from a Commercial Discovery.

Development Operations: operations or activities, including acquiring G\&G Data and drilling Development Wells, conducted under an approved Development Plan.

Discovery: the discovery of an accumulation of Hydrocarbons whose existence until that moment was unproven by drilling.

DSA: Decommissioning Security Agreement.

Encumbrance: a claim on the property of another party in the form of security interest, mortgage, private royalty, free carried interest, assignment of income, production bonus, pledge, lien, charge, title retention arrangement, trust or power, or other form of security or 
interest playing the same role as a security for the payment of any monetary obligation or the observance of any other obligation whether existing or agreed to be granted or created.

Exclusive Operation: those operations and activities carried out under the Contract, the costs of which are chargeable to the account of fewer than all the Parties.

Exploration Operations: operations or activities, including acquiring Geological \& Geophysical Data and drilling Exploration Wells, whose purpose is to explore for accumulations of Hydrocarbons, including Testing conducted in the bore of a well that makes a Discovery

Force Majeure: for the purposes of this Agreement those circumstances beyond the reasonable control of the Party concerned,

HG: the Host Government and any political subdivision, agency or instrumentality thereof of such government, including the Government Oil \& Gas Company.

JOA: Joint Operating Agreement.

Joint Operations: those operations and activities carried out by Operator pursuant to the Contract, the costs of which are chargeable to within the scope of this JOA conducted by Operator on behalf of all Parties, including Exploration Operations, Appraisal Operations, Development Operations, Production Operations, and operations and activities for the purposes of Decommissioning.

Joint Property: at any point in time, all wells, facilities, equipment, materials, information, funds, and property (other than Hydrocarbons) held for use in Joint Operations.

Minimum Work Obligations: the work and/or expenditure obligations specified in the Contract.

NOC: National Oil Company.

Non-Consenting Party: any Party who elects not to participate in an Exclusive Operation.

Non-Operator: any Party to this Agreement other than the Operator.

Operating Committee (Opcom): the committee constituted in accordance to the JOA.

OP: Operating Procedures.

Operator: the Party designated as such in accordance with the Contract and JOA.

Participating Interest: the following rights, benefits, liabilities and obligations of a Participant determined under this agreement:

(a) the obligation, subject to the terms of this agreement, to contribute its Percentage Share of all Joint Expenditure;

(b) the ownership of and the right to receive in kind and to dispose of for its own account its Entitlement produced under this agreement;

(c) the beneficial ownership as a tenant in common of an undivided Percentage Share 


\section{of Joint Venture Property; and}

(d) its Percentage Share of any other right, benefit, liability and obligation accruing to or incurred by a Participant in or arising out of this agreement.

Passmark: the requirements needed to be satisfied to pass a resolution of the Operating Committee by a Majority Vote.

Petroleum Title: a title or licence or production sharing agreement or service contract, and includes any other petroleum prospecting, exploration, retention, production or associated permit, licence, authority or lease issued or to be issued under the Act or any other Law on the application or authority of one or more of the Participants for the purposes of the Joint Venture which confers or may confer a right to prospect, explore for or produce any Petroleum in the Title Area, or which may facilitate the enjoyment of such right, and includes any application for, and any extension, renewal, conversion or substitution of, any of those titles or licences.

PSA: Production Sharing Agreement.

Security: (i) a guarantee or an irrevocable standby letter of credit or irrevocable commercial bank guarantee issued by a bank; (ii) an on-demand bond issued by a surety corporation; (iii) a corporate an irrevocable guarantee issued by a corporation or government; (iv) any financial security required by the Contract or the JOA and (v) any financial security agreed from time to time by the Parties.

Title Area: the whole of the area within the Petroleum Titles and depicted on the Title Area map (if any), including the area within any other additional Petroleum Titles or areas applied for or acquired for the purposes of this agreement.

UKCS: United Kingdom Continental Shelf

Work Program and Budget: a work programme for Joint Operations and corresponding budget for this programme as described and approved in accordance with the Contract. 


\section{Sources and Bibliography}

\section{Primary Sources}

\section{JOA model forms}

1. AAPL JOA forms 610 and 810

2. RMMLF JOA form 1968

3. CAPL OP form 2007

4. OGUK JOA form 2009

5. Norwegian JOA form 2010

6. AMPLA JV form 2009

7. AIPN JOA form 2002

8. Greenlandic JOA form 2008

\section{Cases}

AMEV-UDC Finance Ltd v Austin \& Anor (1986) 68 ALR 185.

BICC plc v Burndy Corp [1985] Ch 232.

Brickles v Snell [1916] 2 AC 599.

Campbell Discount Co Ltd v Bridge [1962] AC 600.

Dunlop Pneumatic Tyre Co Ltd v New Garage \& Motor Co Ltd [1915] AC 79.

Esanda Finance Corp Ltd v Plessnig \& Anor (1989) 84 ALR 99.

Forestry Commission ofNew South Wales v Stefanetto (1976) 8 ALR 297.

Jobson v Johnson [1989] 1 All ER 621 (CA).

Legione and Another v Hateley (1983) 46 ALR 1.

Nutting v Baldwin [1995] 1 WLR 201

Mosaic Oil NL v Angari Pty Ltd (No. 2) Supreme Court of New South Wales [1990] 8 ACLC 780.

Monarch Petroleum NL v Citco Australia Petroleum Ltd [1986] WAR 310 at 352.

O'Dea \& Ors v All States Leasing System (WA) Pty Ltd and Ors (1983) 45 ALR 632. 
Ringrow Pty Ltd v BP Australia Pty Ltd (2005) 222 ALR 306.

Scandinavian Trading Tanker Co AB v Flota Petrolera Ecuatorina [1983] QB 529.

Shiloh Spinners Ltd. V. Harding [1973] A.C. 671 [1973] 1All E.R. 90.

Sport International Bussum BV v Inter-Footwear Ltd [1984] 1 WLR 776.

Steedman v Drinkle [1916] 1 AC 275.

Stern \& Anar v McArthur \& Anor (1988) 81 ALR 463.

Tanwar Enterprises Pty Ltd v Cauchi and Ors (2003) 201 ALR 359.

Wetter v New Pacalta Oils 2 W.W.R. (NS) 290 (Alberta).

\section{Legislation}

1.3.1. British

Partnership Act 1890

Petroleum Act 1998

Petroleum Licensing (Production) (Seaward Areas) Regulations 2008

1.3.3. Norway

Petroleum Activities Act 1996 (Norway)

1.3.4. Canada

Partnership Act 2000 (Government of Alberta)

\section{Books}

Barberis, Danièle, Negotiating Mining Agreements: Past, Present and Future Trends (Klumer Law International, London 1998).

Barton, Barry (ed.), Regulating Energy and Natural Resources (OUP, Oxford 2009).

Bates, J. Leonard, The Origins of Teapot Dome (University of Illinois Press, Urbana 1963).

Bean, Gerard M. D., Fiduciary Obligations and Joint Ventures: The Collaborative Fiduciary Relationship (OPU, Oxford 1995).

Blackett-Ord, Mark, Partnership Law (3rd edn TP, London 2007).

Carter, John D. and others, The Handbook of Joint Venture (Price Waterhouse, Homewood 1988). 
Chatterjee, C., Negotiating Techniques in International Commercial Contracts (Ashgate, Hants 2000).

Comben, Andrew, and others, Joint Ventures \& Shareholder's Agreements (2nd edn Tottel, West Sussex 2008).

Daintith, Terence, and Geoffrey Willoughby (eds), Adrian Hill, United Kingdom Oil \& Gas Law (3rd edn Sweet \& Maxwell, London 2009).

DataMetrics Limited, The Oil and Gas Investment Climate, Changes over a Decade (Canadian Energy Research Institute, Calgary 1984).

David, Martyn R., (ed), Natural Gas Agreements (Sweet and Maxwell, London 2002).

David, Martyn R., Upstream Oil and Gas Agreements (Sweet and Maxwell, London 1996).

Derman, Andrew B., International Oil and Gas Joint Ventures: A Discussion with Associated Form Agreements (American Bar Association, Tulsa 1992).

Derman, Andrew B., Joint Operating Agreement: Working Manual (American Bar Association, Tulsa 1986).

Derman, Andrew B., Model Form International Operating Agreement, An Analysis and Interpretation of the 1995 Form (American Bar Association, Tulsa 1997).

Derman, Andrew B., The New and Improved 1989 Joint Operating Agreement: A Working Manual (American Bar Association, Tulsa 1991).

Duncan, W. D., Joint Ventures Law in Australia (2nd edn The Federation Press, Sydney 2005).

Duval, Claude and others, International Petroleum and Exploration Agreements: Legal, Economic \& Policy Aspects (2nd edn Barrows, New York 2009).

Frankel, P.H., Essentials of Petroleum: A key to Oil Economics (2nd Frank Cass, London 1976).

Gao, Zhiguo, International Petroleum Contracts: Current Trends and New Directions (Graham \& Trotman, London 1994).

Glusman, David H. and Gabriel Daniel Martin Ciociola, Fiduciary Duties and Liabilities, Tax and Trust Accountant's Guide (CCH, Chicago 2006).

Dezhi Peng, David, Insurance and Legal Issues in the Oil Industry (Graham \&Trotman, London 1993).

Gordon, Greg and John Paterson (eds), Oil and Gas Law: Current Practice and Emerging Trends (DUP, Dundee 2007).

Haag, Jim, The Acquisition \& Divestiture of Petroleum Property, A Guide to the Tactics, Strategies \& Processes Used by Successful Companies (Penwell, Tulsa 2005). 
Jennings, Anthony (ed), Oil and Gas Production Contracts (Sweet \& Maxwell, London 2008).

Jennings, Anthony, Oil and Gas Exploration Contracts (2nd edn Sweet \& Maxwell, London 2008).

Johnston, Daniel, International Exploration Economics, Risk, and Contract Analysis (PenWell, Tulsa 2003).

Johnston, Daniel, International Petroleum Fiscal Systems and production sharing contracts (Penwell, Oklahoma 1994).

Johnston, David and Daniel Johnston, Introduction to Oil Company Financial Analysis (Penwell, Tulsa 2006).

Kronman, George E. (ed.) and others, International Oil and Gas Ventures: A business Perspective (The American Association of Petroleum Geologists, Tulsa 2000).

Lowe, John S., Oil and Gas Law - in a nut Shell (5th edn Thompson Reuters, Saint Paul 2009).

Markham, Jesse W., Anthony P. Hourihan, and Francis L. Sterling, Horizontal Divestiture and the Petroleum Industry (Ballinger, Cambridge 1977).

Mazeel, Muhammed, Petroleum Fiscal Systems and Contracts (Diplomica Verlag, 2010 Hamburg).

Mikesell, Raymond F., Petroleum Company Operations \& Agreements in the Developing Countries (Resources for the Future, Washington 1984).

Morgan, Bronwen and Karen Yeung, An Introduction to Law and Regulation: Text and Materials (CUP, Cambridge 2007).

Nakhle, Carole, Petroleum Taxation Sharing the Oil wealth, a study of petroleum taxation yesterday, today and tomorrow (Routledge, London 2008).

Norton, John C. and Donald A. Rowe, Accounting and Auditing Guide for United Kingdom Oil and Gas Exploration and Production (The Institute of Chartered Accountants in England and Wales, London 1978).

Peng, David Dezhi, Insurance and Legal Issues in the Oil Industry (Graham \&Trotman, London 1993).

Picton-Turbervill, Geoffrey (ed.), Oil and Gas: A practical handbook (Global Law and Business, London 2009).

Roberts, Peter, Joint Operating Agreements:A Practical Guide (Globe Law Business, London 2010).

Smith, Ernest E. and others, International Petroleum Transactions (3rd edn RMMLF, Westminster 2010). 
Taverne, Bernard G., An Introduction to the Regulation of the Petroleum Industry: Law, Contracts and Conventions (Graham \& Trotman, London 1994).

Taverne, Bernard. G., Co-Operative Agreements in the Extractive Petroleum Industry (Kluwer Law International, Hague 1996).

Taverne, Bernard. G., Petroleum, Industry and Governments: A study of the Involvement of Industry and Governments in the Production and Use of Petroleum (2nd edn Kluwer Law International, Alphen aan den Rijn 2008).

Taylor, Michael P. G. and Sally M. Tyne, Taylor and Winsor on Joint Operating Agreements ( $2^{\text {nd }}$ edn Longman, London 1992).

Thornton, William W., The Law Relating to Oil and Gas (Law Book Publishers, Cincinnati 1904).

Thorpe, Chris, Fundamentals of Upstream Petroleum Agreements (CP Thorpe, UK 2008).

Walde Thomas W. and George K. Ndi (ed.), International Oil and Gas Investments, Moving Eastward? (Graham \& Trotman/Martinus Nijhoff, London 1994).

Wilkinson, Chris (ed.), Joint Ventures \& Shareholders' Agreements (3rd edn Bloomsbury Professional, West Sussex 2009).

Wilkinson, John, Introduction to Oil \& Gas Joint Ventures: Volume one, United Kingdom Continental Shelf (OPL, Ledbury 1997).

Wils, John Ewan and C. Neilson (eds), The Technical and Legal Guide to the UK Oil and Gas Industry (Aberlour Press, Aberdeen 2007).

Wright, Charlotte J. and Rebecca A. Gallun, Fundamentals of Oil \& Gas Accounting (5th edn Penwell, Tulsa 2008).

Yergin, Daniel, The Prize: The Epic Quest for Oil, Money \& Power (2nd edn Free Press, New York 2008).

\section{Articles and book chapters}

Aldersey-Williams, Judith, Application of the anti-deprivation rule to forfeiture in oil and gas contracts (2010) International Energy Law Review 196.

Asmus, David F., 'The 1995 Model Form International Operating Agreement' (1996) 14 Journal of Energy \& Natural Resources Law 14, 22.

Baily, James E. H., Equitable Liens and Engineering, Procurement and Construction Contracts in the Oil and Gas Industry (2007) Journal of Energy and National Resources Law Vol 25 No 4.

Barnhill, Kenneth E. Jr., 'Taxation of Oil and Gas Operating Agreements, The Scope and Application of I. T. 3930' (1953-1954) 26 Rocky Mountain Law Review 133. 
Bartlett, Richard H., 'Rights and Remedies of an Operator vis-à-vis a defaulting non-operator under Joint and Unit Operating Agreements' (1972) 10 Alberta Law Review 291.

Bean, Gerard M. D., 'Joint ventures and other relationships: remedies for failure to disclose information` (1994) 12 Oil \& Gas Law \& Taxation Review 280-282.

Bentham, R. W., 'The Negotiation of Agreements' (1987) 5 Journal of Energy \& Natural Resources Law 134.

Bentham, R.W., 'Joint operating agreements - default' (1990) 8(1) Journal of Energy \& Natural Resources Law 63.

Black, Alexander J. and Hew R. Dundas, 'Joint Operating Agreement: an international comparison from petroleum Law` (1992) 8 Journal of Natural Resources \& Environmental

Boigon, 'Howard L. The joint operating agreement in a hostile environment: Part 2' (1987/88) 6(12) Oil and Gas Law Taxation Review 361-374.

Boigon, 'Howard L., The joint operating agreement in a hostile environment: Part 1' (1987/88) 6(11) Oil and Gas Law Taxation Review 320-325.

Boigon, Howard L. and Christine L. Murphy, 'Liabilities of Nonoperating Mineral Interest Owners' (1979-1980) 51 University of Colorado Law Review 153.

Bullough, John B. B., The Norwegian Experience - The Role of a Non-Operator` (1996) 11 Oil and Gas Finance \& Accounting.

Ching, Jane, The statutory ground to award security for costs against an impecunious company: should we mourn its passing? (2009) Civil Justice Quarterly 470.

Christiansen, Mark D., Oil and Gas Law, Recent Oklahoma Cases Interpreting Oil and Gas Joint Operating Agreements (2004) 57 Oklahoma Law Review 850-852.

Conine, Gary B., 'Property Provisions of the Operating Agreement, Interpretation, Validity, and Enforceability’ (1988) 19 Texas Tech Law Review 1265.

Curran, John F., 'American Tax Considerations in the Drafting of Canadian Joint Operating Agreements' (1970) 8 Alberta Law Review 194.

Davis, Richard, Remedial security and construction contracts (2011) 27 (6) Construction Law Journal 480.

Dawborn, David and John Waite, 'Contractual forfeiture of joint venture interests: are such clauses enforceable' (1990) 8 Oil \& Gas Law \& Taxation Review 389-392.

Douglas, H., 'Gulf of Mexico Oil Spill: Likely Impact on UK Regulation and Contractual Arrangements' (2010) 8(3) Oil Gas and Energy Law.

Dulaney, Michael and Robert Merrick, 'Legal Issues in Cross-Border Oil and Gas Pipelines' (2005) 23 Journal of Energy \& Natural Resources Law 247.

Etikerentse, G., 'Taxation and Other Fiscal Provisions in the Petroleum Upstream Sector' (2003) 5 Oil Gas and Energy Law. 
Franklin, Helen, 'Irretrievable Breakdown? A Review of Operator/Contractor Relationships in the Offshore Oil and Gas Industry' (2005) 23 Journal of Energy \& Natural Resources Law 1.

Glancy, Dorothy J.,'Breaking up can be hard to do: partitioning jointly owned oil and gas and other mineral interests in Texas` (1998) 33 Tulsa Law Journal 705-764.

Hardy, Michael, 'Better Safe than Sorry, Apologies, Liability and the Media' (2000) 19 Australian Mining Petroleum Law Journal 225.

Hewitt, Geoff, 'The AIPN Model Form International Operating Agreement 2002` (2003) 11 International Energy Law Taxation Review 309-311.

Hudec, Al and Joni Paulus, 'Current Oil and Gas Issues in Canada and the 1990 CAPL Operating Agreement' (1992)10 Journal of Energy \& Natural Resources Law 194.

James, Richard, 'Kansas oil and gas law: defining the duty between participants in a joint operating agreement' (1999) 39 Washburn Law Journal 128-142.

Johnston, Daniel, 'Contract Terms Worldwide: A Case for New Frameworks' (2004) 2(3) Oil Gas and Energy Law.

Joint Ventures' (2003) 22 Australian Resources \& Energy Law Journal 153-160.

Jolanta Olszewska, 'Operators' Offshore Responsibilities and Liabilities Increased in Australia’ (2002) 21 Australian Mining Petroleum Law Journal 104.

Jones, Lee, 'Problems Presented by Joint Ownership of Oil, Gas and Other Minerals' (19531954) 32 Texas Law Review 717.

Josephson, Michael D., 'How Far Does the CAPL Travel? A Comparative Overview of the CAPL Model Form Operating Procedure and the AIPN Model Form International Operating Agreement' (2003) 41(1) Alberta Law Review 1-3.

Kaasen, Juris Knut, 'Scope of Joint Operating Agreements in Norway' (Petroleum Law Seminar, St. Raphael, 2000).

Knull, Will H. III and others, Accounting for Uncertainty in Discounted Cash Flow Valuation of Upstream Oil and Gas Investments (2007) 25 Journal of Energy Natural Resources Law 275.

Lauriol, Thierry M., Legal Aspects of Creating Security Interests over Mining Titles in the States Parties to the OHBLA (2001) Journal of Energy and National Resources Law Vol 19 No 32001.

Law 49-79.

Lishman, Michael, 'Penalties and Relief Against Forfeiture of Joint Venture Interests' (2008) 27 Australian Review Energy Law Journal 223.

Maclean, James A., The 1990 CAPL Operating Procedure, an Overview of the Revisions (1992) 30 Alberta Law Review 152.

MacWilliam, D. A., 'Fiduciary Relationships in Oil and Gas Joint Ventures' (1970) 8 Alberta Law Review 233. 
Maloney, D. A. W., 'Managing the Multi-Participant Joint Venture' (1988) 7(2) Australian Mining and Petroleum Law Bulletin 112.

Maloney, David A. W., 'Australia's Offshore Petroleum Work Programme Bidding System' (2003) 21 Journal Energy \& Natural Resources Law 112.

Mandler, Pia, 'New Oil \& Gas UK standard joint operating agreement (JOA)' (2008) 5 International Energy Law Review 111-112.

McConnel, Scott, Project Financing in the Energy Industry and its Impact on Completion Risk (2001) 20(2) Australian Mining and Petroleum Law Journal 148.

Michael Lishman, Penalties and Relief Against Forfeiture of Joint Venture Interests (2008) 27 Australian Resources and Energy Law Journal 226.

Miles, Catia Malaquias, 'AIPN 2002 Model Form Joint Operating Agreement in Oil and Gas Joint Ventures' (2003) 22(2) Australian Resources and Energy Law Journal 153.

Mills, Michael, 'Insurance and Risk Solutions for Commercial Projects' (2001) 20 Australian Mining Petroleum Law Journal 46.

Mosburg, Lewis G., 'The joint operating agreement: partnership or not?' (1986) 4(2) Journal of Energy \& Natural Resources Law. 80-84.

Mundt, Preston R., 'The Assignor Giveth and the Operator Taketh Away, Oil and Gas Working Interest Owners Beware of Continuing Liability' (2007-2008) 40 Texas Tech Law Review 419.

Nicholls, Robert C., A review of some aspects of the organization and financing of mineral resource ventures University of South Wales Law Journal Vol 1271

Okafor, Chidinma Bernadine, 'Model Agreements for Joint Development, a Case Study' (2007) 25 Journal of Energy \& Natural Resources Law 98.

Parr, Christopher, 'Relief against forfeiture under joint operating agreements' $(1986 / 87)$ 5(10) Oil Gas Law Taxation Review 253-255.

Pennington, Elizabeth, 'Issues for new entrants to the UKCS - a legal analysis' (2002) International Energy Law Taxation Review 281.

Ramlogan, Rajendra, 'State Participation in Joint Ventures: The Republic of Trinidad and Tobago Experience' (1992) 10 J. Energy \& Natural Resources Law 284.

Randall Wood, Oil and Gas, A.A.P.L. Form 610 Model Form Operating Agreement, Imposing Limitations on the Operator's Ability to Require Contribution from Nondefaulting Nonoperators (1983) 36 Oklahoma Law Review 733.

Rawlings, Philip, The changing role of the trustee in international bond issues (2007) Journal of Business Law 43.

Ray, George E. and Oliver W. Hammonds, 'Oil and Gas Operating Agreements' (1949) 27 Taxes 617.

Roberts, Peter, 'Fault lines in the joint operating agreement: decision-making' (2008) 8 International Energy Law Review 290-294. 
Roberts, Peter, 'Fault lines in the joint operating agreement: forfeiture' (2008) 7 International Energy Law Review 274-278.

Sabey D. O. and others, 'Indemnity and Insurance Clauses in Joint Venture, Farmout and Joint Operating Agreements' (1970) 8 Alberta Law Review 210.

Shilliday, Daniel B. and others, 'Contractual Risk-Shifting in Offshore Energy Operations' (2006-2007) 81 Tulane Law Review 1579.

Smith, Ernest E., 'Joint Operating Agreement Jurisprudence' (1994) 33 Washburn Law Journal 834.

Sneed, Joseph T., 'More About Associations in the Oil and Gas Industry' (1954-1955) Texas Law Review 168.

Wall, Guy E., 'Joint oil and gas operations in Lousiana' (1992) 53 Louisiana Law Review 79117.

Warne, Penelope and Judith Aidersey-Williams, 'Oil and Gas Contracts in the UKCS -How to Survive Them' (2001) 19 Journal of Energy \& Natural Resources Law 302

Weems, P. R. and M. Bolton, 'Highlights of Key Revisions - 2002 AIPN Model Form International Operating Agreement' (2003) 1 Oil and Gas Energy Law.

Weidman, John D., 'Oil and Gas, Operator's Liens in Bankruptcy, The Model Form Operating Agreement Versus the Trustee in Bankruptcy's Avoiding Powers' (1984) 37 Oklahoma Law Review 141.

Willoughby, G. D. M., 'Forfeiture of Interests in Joint Operating Agreements' (1985) 3 Journal of Energy \& Natural Resources Law 256-265.

Worboys, Hilary, 'Boiler plate or boiler fuel? A critical analysis of a standard term of the North Sea joint operating agreement' (1986/87) 5(12) Oil Gas Law Taxation Review 299 302.

\section{Conference and research papers}

Dundas, Hew, 'Joint Operating Agreements: An Introduction` (1994 Summer Programme:

UK Oil and Gas Law, CPMLP 09/09, 1994).

Bean, Gerard M. D., Fiduciary Obligations and Joint Ventures: the Joint Operating

Agreement`(1994 Summer Programme: UK Oil and Gas Law, CPMLP 09/09, 1994).

Gaymer,Vivien, 'Sole Risk and Non-Consent under U.K., Joint Operating Agreements` (1994

Summer Programme: UK Oil and Gas Law, CPMLP 09/09, 1994).

Fawzi, Howayda Hassan, The Evolution of the Legal and Contractual Framework for

Exploration and Production of Oil in Sudan and the United Kingdom, A comparative

approach to developing and developed countries $(\mathrm{PhD}$ Thesis presented to the University of 
Dundee, 1996).

Mildwaters, Kenneth Charles, Joint Operating Agreements, A Consideration of Legal Aspects Relevant to Joint Operating Agreements used in Great Britain and Australia by Participants thereto to Regulate the Joint Undertaking of Exploration for Petroleum in Offshore Areas with Particular Reference to their Rights and Duties $(\mathrm{PhD}$ Thesis presented to the University of Dundee, 1990) 674-934.

Wright Ashley and others, Association of International Petroleum Negotiations Event, Forewarned is Forearmed: Joint Ventures and Insolvency 26 February 2009.

\section{Websites}

$<$ http://www.landman.org/> Accessed 5 March 2012.

$<\mathrm{http}$ ://www.aipn.org/> Accessed 5 March 2012.

$<$ http://www.landman.ca/> Accessed 5 March 2012.

$<\mathrm{http}: / /$ www.oilandgas.org.uk> Accessed 5 March 2012.

$<$ https://www.og.decc.gov.uk/upstream/licensing/joa.htm> Accessed o10 February 2012.

$<$ http://www.mosburgoil-gas.com/> Accessed 19 June 2010.

$<$ http://www.inp.gov.mz/Legal-Framework/EPCC-Model> Accessed 3 March 2012.

$<$ http://oilprice.com/Energy/Crude-Oil/Extreme-Offshore-The-Hunt-for-Hard-to-FindCrude.html Accessed>1 March 2012.

$<$ http://www.ft.com/cms/s/0/ad7dc7c6-b4c3-11e0-a21d00144feabdc0.html\#axzzliKBvMiFx> Accessed 1 March 2012.

$<$ http://library.findlaw.com/2003/Feb/24/132507.html> Accessed 1 March 2012.

<http://www.inp.gov.mz/Legal-Framework/EPCC-Model> Accessed 1 March 2012.

$<$ http://www.anp.gov.br/brasil-rounds/round10/ingles/edital.asp> Accessed 1 March 2012.

$<$ http://www.inp.gov.mz/Legal-Framework/EPCC-Model> Accessed 1 March 2012.

$<$ http://www.landman.ca/pdf/operating_procedures/2007/final/Modifications\%20to\%20199

\%20Oper\%20Proc\%20(Aug\%2016\%202007).pdf> Accessed 02 March 2012.

$<$ http://www.presalt.com/> Accessed 01 March 2012.

$<$ http://www.aipn.org/aboutus/> Accessed 2 March 2012.

$<$ http://www.regjeringen.no/en/dep/oed/Documents-and-publications/Laws-and-rules-

2/Rules/2007/framework.html?id=455506>Accessed on 2 March 2012.

$<$ http://www.ampla.org/scripts/cgiip.exe/WService=AMPLA/ccms.r?PageId=50 $>$ Accessed 2 March 2012. 
$<$ http://www.ampla.org/scripts/cgiip.exe/WService=AMPLA/ccms.r?PageId=10016> Accessed 07 March 2012.

$<$ http://www.tklaw.com/resources/documents/Protecting\%20Oil\&\%20Gas\%20Lien\%20\%20Derman.pdf> Accessed 07 March 2012.

$<$ https://www.og.decc.gov.uk/upstream/licensing/joa.htm> Accessed 2 March 2012.

$<$ http://www.oilandgasuk.co.uk/aboutus/aboutus.cfm> Accessed 2 March 2012.

$<$ http://www.npd.no/en/About-us/> Accessed 07 March 2012.

$<$ http://www.rmmlf.org/pubs/order.htm> Accessed on 07 March 2012.

$<$ http://www.landman.ca/store/capl_publication_list.php> Accessed 2 March 2012.

$<$ http://oxforddictionaries.com/view/entry/m_en_gb0664810\#m_en_gb0664810>Accessed

2 March 2012.

$<$ http://www.ampla.org/lib/pdf/Conf10/Papers/5B\%20FP\%20MacGibbon.pdf $>$ Accessed 07 March 2012. 